\title{
EMERGENCE AND DEVELOPMENT OF THE NATIONAL INNOVATION SYSTEMS CONCEPT
}

\author{
Naubahar Sharif * \\ Division of Social Science, The Hong Kong University of Science and Technology, Clear \\ Water Bay, Kowloon, Hong Kong SAR
}

\begin{abstract}
Adopting a science and technology studies (S\&TS) perspective and organized around eight major themes, this paper analyzes the development of the National Innovation Systems (NIS) concept, examining how the formal body of codified NIS knowledge was produced, developed and spread, and how it is used. In order to trace its history, I interviewed major advocates of the NIS concept to understand how and why it has become so widespread in academic and policymaking circles. The eight themes serve as 'missing pieces' to explain the early history of the NIS concept.

Keywords: National Innovation System; Origins; Development; Diffusion; History
\end{abstract}

* Tel.: +852 2358 7826; Fax: +852 23350014

Email address: sosn@ust.hk 


\section{Emergence and Development of the National Innovation Systems}

\section{Introduction}

The national innovation systems (NIS) concept first appeared in the mid1980s in the context of debates over industrial policy in Europe. Since then, an international body of literature documents the growing influence of the NIS approach. Several supranational organizations-most notably the Organisation for Economic Cooperation and Development (OECD)—have absorbed or are beginning to use the NIS concept as an integral part of their analytical perspective (Lundvall et al. 2002: 214). ${ }^{1}$ The innovation systems approach enjoys wide currency in Scandinavia and Western Europe, in both academic and policymaking contexts. ${ }^{2}$

One account of NIS is the "set of institutions that (jointly and individually) contribute to the development and diffusion of new technologies. These institutions provide the framework within which governments form and implement policies to influence the innovation process. As such, it is a system of interconnected institutions to create, store, and transfer the knowledge, skills, and artifacts which define new technologies" (Metcalfe 1995 in OECD 1999: 24). The actors within a system, as well as contextual factors, are all

\footnotetext{
${ }^{1}$ In addition to the OECD, the organizations involved include the European Union (EU), the United Nations Conference on Trade and Development (UNCTAD), and to a lesser extent (thus far) the World Bank and the International Monetary Fund. Lundvall, et al. (2002: 214) claim that the United States National Academy of Sciences, too, has recently brought the innovation systems concept into its vocabulary and now uses it as a framework for analyzing science and technology policy in the United States.

${ }^{2}$ Finland was the first country to adopt the concept of an NIS as a basic category of its science and technology policy, and Sweden has given the concept legitimate status in its own way by naming a new central government institution (an 'ämbetsverk') VINNOVA, or the 'Systems of Innovation Authority.'
} 
important elements of any given system for the creation and use of knowledge for economic purposes.

Working under the umbrella of science and technology studies (S\&TS), I adopt a social constructivist approach to trace the story of the NIS concept from its origins through its eventual dissemination to other sites. Bringing this perspective to the issue raises many questions about the background of the concept that are best addressed by reference to personal accounts of those who participated in its genesis, evolution, and propagation. In historical context, I consider how the influence of the NIS approach in discussions of science and technology policy in the 1990s has grown in spite of ambiguities and differences in the use of the term. ${ }^{3}$ In this paper, I adopt a sociological and historical perspective to bring to the fore features of NIS not commonly accorded sufficient attention. This focus precludes an interest in the use of NIS as a rhetorical tool.

To understand the background to the NIS concept, we must consider the work that was involved in constructing the NIS approach as a body of formally codified knowledge. It did not emerge naturally, fully constructed; rather, it resulted from the strategic maneuverings of a group of original champions of the approach who had specific agendas and wished to achieve definite results through the approach's construction and diffusion. In other words, the NIS body of knowledge was actively 'produced.' In this paper I first discuss what we know about the emergence and development of the innovation systems concept from both an innovation studies perspective and a broadly S\&TS perspective. Then, I describe the research methodology of the study and introduce the cast of characters involved in creating the NIS conceptual program, considering the concept in greater depth. In the fourth

\footnotetext{
${ }^{3}$ Although other accounts adequately address some background questions (see, for example, Lundvall 2003; Edquist 2005), the history given here is more than a simple chronological enumeration of events.
} 
section I utilize concepts from S\&TS, sociology, and history to examine the social construction and history of the NIS concept and its use, with special concern for the roles played by the community of academics and policymakers who were (and are) influential in generating and sustaining it.

\section{Conceptual Framework and Review of the Literature}

Although there is a growing body of literature on the economic, policy-related, and theoretical aspects of innovations in general and the NIS concept in particular, to the best of my knowledge there is no material that discusses the history of the NIS conceptual approach from a constructivist standpoint. ${ }^{4}$ Moreover, disagreements among leading practitioners in the field have not been analyzed from such a standpoint. ${ }^{5}$ In this paper, I borrow from S\&TS studies of controversies and rhetoric, as well as the sociology of technology, to study these neglected aspects of the emergence and history of the NIS concept.

From a social constructivist perspective, the focus on the NIS concept is a departure from the customary sites and objects of analysis in the sociology of science and technology, which have hitherto been dominated by the examination of scientific knowledge and material artifacts. While the NIS concept is not a material technology in the same way that Bakelite, bicycles, and nuclear missiles are, as a concept it still impinges on human consciousness and behavior, and is, therefore, a proper target for analysis.

\footnotetext{
${ }^{4}$ For other views of the history see, for example, Fagerberg et al. (2005), Nelson (2000), Lundvall (1998), Freeman (1995), Nelson (1993), and Lundvall (1992).

${ }^{5}$ My usage of the term 'debate' functions differently from the common usage of the term in science and technology studies (S\&TS) analyses. I do not use the term to refer to antagonistic groups pitted against and intellectually patronizing one another. Rather, my usage of the term 'debate' or 'controversy' in this paper more accurately refers to disagreements-entirely amicable-about ambiguities or uncertainties that practitioners of the NIS concept struggle with in regard to the usage or meaning of the NIS concept.
} 
Beyond work in the S\&TS field, and to some extent in the history of technology, relatively little attention has been paid to the historical process through which knowledge and artifacts become good facts or successful technologies; such an understanding of knowledge production is often dismissed by scholars external to the sociology of science and technology as inconsequential or unimportant (see, for example, Matthews 1998; Slezak $1989,1994)$. Once a piece of scientific knowledge or tangible artifact becomes black-boxed, it acquires an air of inexorability, as if it were the only possible solution to the set of problems to which it is applied (Sismondo 2004). ${ }^{6}$ As a corrective to such a development, in this paper I make the NIS concept itself the object of analysis, bringing into the foreground the basis of its success.

This study is one of the few in S\&TS to examine a major academic and policymaking tool by combining interviews and document analysis in its methodology. Literature in the field that addresses technology policy is dominated by the main preoccupations of the decision-makers and their clients, namely the definition of priorities and the allocation of resources (Shils 1968; Gilpin 1968; Averch 1985). Most of these studies treat science policy as a 'black box,' however, focusing only on the inputs and the outputs of a given policy in practice.

Even Latour's work, Science in Action (1987), focuses attention exclusively on representational issues. Armed with his version of 'technoscience,' Latour traces the activities and social interactions of scientists and engineers, building an analytical framework within which various translations identify sociotechnical networks comprising such heterogeneous domains as 'science,' 'technology,' 'science policy,' and

\footnotetext{
${ }^{6}$ In this context, S\&TS appropriates the engineers' term 'black box,' normally used to describe a predictable input-output device, something the inner workings of which need not be known for it to be used.
} 
'commercial endeavors.' Latour's Aramis (1996) also discusses technology policy, but the attention devoted to technology policy and innovation is limited in the midst of competing sources and voices. ${ }^{7}$

Cambrosio et al. (1990) followed up on Latour's (1987) work by adopting an ethnographic approach in order to study how the Québec government in Canada devised and applied biotechnology policy measures. Fifteen years later our understanding of the technology policymaking process has scarcely improved. A notable exception is Guston (2000, especially pp.37-63), who tackles science policy issues, albeit from a principal/agent perspective, by discussing the origins and evolving nature of state involvement in science. Only very recently has there been a renewed effort to study how policymaking practices are influenced, conditioned, and coconstituted by conceptual tools such as the national innovation systems concept.

Similar conceptual tools that have received attention for their roles in science and technology policy from an S\&TS standpoint are the 'New Production of Knowledge' approach of Gibbons et al. (1994) and the 'Triple Helix Model' (Etzkowitz and Leydersdorff 1997, 1998, 2000). In contrast to the NIS concept, these perspectives have been debated and discussed broadly in S\&TS (see, for example, Hicks and Katz 1996; Godin and Gingras 2000; Ziman 2000; Cohen et al. 2001; Jansen 2002; Shinn 2002; Pestre 2003). This neglect of the NIS concept in the S\&TS literature is somewhat surprising because, although the NIS perspective is not yet as influential as Gibbons's 'New Production of Knowledge' approach, it seems to exhibit the institutional trappings and claim as many adherents as the 'Triple Helix Model.'

\footnotetext{
${ }^{7}$ Latour's (1996) account in Aramis is interwoven with and competing with a number of other voices: it is part sociological treatise, part novel, part philosophical meditation, and part literary experiment, blended with a quasi-fictional writing technique.
} 
Contributions to critical S\&TS scholarship on the NIS approach include Miettinen (2002), which focuses on the emergence and use of the national innovation systems conceptual approach in Finland in the 1990s. Miettinen expertly analyzes the approach's political rhetoric as used in technology policymaking in Finland by studying the relationship between innovation research and the production of policy language by international and national policy agents. Miettinen concludes that, although the NIS approach has become firmly established in the science and policy language, it is alone an insufficient basis for policymaking in Finland. Such an analysis—of the NIS concept's political rhetoric-is not the objective of this paper.

Albert and Laberge (2004) use a largely ethnographic lens through which to study how international organizations (in particular, the OECD) and regional public administrations (in their case, that of the province of Québec, Canada) apply NIS legitimation and dissemination processes. They find that, rather than being grounded in the critical evaluation of a set of possible models, the dissemination and use of the innovation systems approach within the public sector are closely linked to its perceived scientific prestige. ${ }^{8}$

Focusing on the social dynamics of the actors involved, in either policymaking or academia, to take stock of the prevalence or diffusion of the NIS concept is not a tact that has been widely employed by scholars. ${ }^{9}$ Scholarship in the economics of technological change unquestioningly employs the NIS concept without, however, always recognizing the multiple interpretations embodied in the idea. ${ }^{10}$

\footnotetext{
${ }^{8}$ For other critical S\&TS scholarship on the NIS, see also Albert (2001) and Sharif (2003, 2004).

${ }_{9}^{9}$ To be sure, several studies have approached a similar issue in a geographically bounded, country-specific context. See, for example, Jääskelainen (2001), who analyzes the use of the innovation systems idea in Finland as a by-product of his analysis of Porter's Diamond Model and also of cluster analyses.

${ }^{10}$ For example, Castellaci et al. (2005) identify two dominant traditions in the innovation systems literature, but my account challenges their findings. They describe the theory of innovation at both the microeconomic level (focusing on individuals within a firm) and the
} 
Lundvall $(1992,1998,2003)$, also offers a description of the dominant strands in the innovation systems program, but his account is a more catalog of facts. Lundvall is widely recognized as a central proponent of the innovation systems approach, and his writings on the inception, diffusion, and use of the innovation systems concept favor, perhaps understandably, the version of the concept in which use-producer relations are central, a version which he played a key role in developing.

\section{Methods}

In some ways, the scant attention paid to the history and social construction of the NIS concept is not surprising because it is a relatively recent development. From an alternative standpoint, however, it needs explanation given the extensive use of the NIS approach in academic and government circles. In the academic domain, the study of innovation systems is central to scholarly research programs at numerous research institutes and centers. These research centers are usually interdisciplinary units, including economics, business studies, S\&TS, and even some branches of sociology.

I interviewed many of the individuals making up the core group of scholars associated with innovation systems research during the autumn of 2003. The interviews were semi-structured and I developed a guide to help direct conversation. These guides, provided in advance to my interviewees, did not always articulate the exact wording of the questions that I would ask or the order in which I would raise particular issues, but rather provided an

mesoeconomic level (focusing on firms within an industry). I find their approach wanting. They posit an over-simplified dichotomy of traditions: There are, in their terms, only an 'historicalempirical approach' and an 'interactive learning-based approach.' Not only is this dichotomy false in the sense that there is an overlapping spectrum of 'traditions' within the innovation systems program, but also my interview findings are inconsistent with their characterization of the individuals working within one or the other of the two traditions they identify. 
outline of themes that I wanted to cover during the course of the interview. This technique helped me ensure that I covered all issues of particular interest to me, while also allowing flexibility to tailor the interview according to the responses of the interviewees. All the interviews were arranged in advance, digitally recorded, and conducted without significant interruptions. I took some handwritten notes during these interviews, but mostly focused my attention on the oral discussion. The audio recordings were subsequently transcribed and analyzed. Each of the interviews lasted between one and two-and-a-half hours. Table 1 presents summary information on my interviewees, including their institutional affiliations at the time I interviewed them, and selected publications indicating their role in the development/diffusion of the innovation systems concept.

\section{[TABLE 1 HERE]}

In addition to these semi-structured interviews, I also conducted a number of informal but in-depth conversations with other relevant individuals who have been influential in the development of the innovation systems concept in both academia and policymaking. Unlike the first set of interviews, these were unstructured, unscheduled, and usually took place at conferences and similar meetings. These conversational interviews were not recorded and were, in general, shorter, lasting between 30 minutes and two hours. In one case, I did take some handwritten notes, but in most cases I wrote up 'interview notes' only after the conversations. Details about this group are provided in Table 2.

[TABLE 2 HERE] 
It is striking to note how widespread this work has been, with important contributions coming from the United Kingdom, most Scandinavian countries, several Western European nations, and to a lesser extent the United States (see Appendix).

\section{Genesis and Development of the NIS Concept}

The NIS concept emerged in a very specific set of sociological circumstances. It was not the only solution to a pressing set of problems at the time of its genesis (understanding competitiveness at the country level). The specific circumstances surrounding its origins are not always given the full attention they deserve in the innovation systems literature. There are key 'missing pieces' in the history of the innovation systems conceptual program, partly explained through various controversies among NIS concept's practitioners. The practitioners seldom (and always only tangentially) refer to these missing pieces in the innovation systems literature, leaving the controversies to 'float' above the mainstream academic and policy debates.

I organize my history of the NIS concept around eight themes, clarifying these controversies and explicating the missing pieces in order to situate the development of the NIS concept more accurately and to understand better how the concept operates and acquired the power it has today. Each of the eight inter-related topics represents either a missing piece or a controversy within the NIS concept's history. Additionally, during the development of the NIS concept, there were a number of social, political, and economic issues that are important to consider. These issues can be classified into two areas: closure and stabilization; and the wider context. By revealing these 'missing pieces' and connecting them to the context of the NIS concept's emergence, I trace how consensus behind the NIS concept 
developed as a result of a reaction to the prevailing orthodoxy in economics, the wider geopolitical context, and strategic links between the academic and policy worlds. My analysis helps to explain the promulgation of varying interpretations of the concept on the part of different actors in the innovation systems literature.

This section forms the backbone of the paper and is based primarily on my interviews with central proponents of the NIS concept.

\subsection{Ambiguity Surrounding the Academic or Policymaking Origins of the NIS Concept}

Let us first consider whether the NIS concept was developed originally in academia or in policymaking. Policymaking institutions here include supranational organizations, such as the OECD's Directorate for Science, Technology and Industry (DSTI), which recommends policies to countries, and also single nation-states that formulate innovation and technology policies. Participants in the field of innovation systems often assume that the concept originated in academia and then moved to the policymaking sphere. Interestingly, there is no consensus among practitioners about whether the roots of the NIS concept were solely and primarily academic or policy related. My interviews suggest that ascribing the origins of the concept solely to either of the two fields of activity (academia or policymaking) is incorrect: The concept arose simultaneously in academia and policymaking (with regards to the latter, specifically in the OECD) at around the same time. This was possible because many of the key proponents of the concept occupied roles in both academia and policymaking organizations.

Keith Smith is unequivocal in his view that the concept had policy roots: "[T] he key thing about it [NIS] . . is that it wasn't really developed as a 
theoretical concept. It wasn't a properly elaborated conceptual apparatus. It was really developed as a policy concept" (Smith interview, 13 Oct 03). Similarly, in the view of Staffan Jacobsson, the innovation systems concept took off because a policy vehicle/agency in Sweden-the Swedish Board for Technical Development-initiated a study in 1988 by asking a number of researchers to discuss and conduct research on what they called Sweden's Technological System (Jacobsson interview, 17 Oct 03).

For Bengt-Åke Lundvall, determining the NIS concept's origins is to some extent an arbitrary chicken-or-egg exercise: "[l]t's difficult to say whether it was primarily an academic approach to inform policymaking or the other way around" (Lundvall interview, 20 Oct 03). Lundvall claims that the two major contributions in academia and policymaking that launched the NIS concept were a major book edited by Giovanni Dosi, Christopher Freeman, Richard Nelson, Gerald Silverberg, and Luc Soete on technical change published in 1988 (discussed below), and a report published by the Technology/Economy Programme (TEP) in the OECD in 1992.

Dosi et al. (1988) combined the writings of economists and noneconomists who had been involved in critical assessments of the way in which orthodox economic theory deals with technical change. The book was supported by the International Federation of Institutes for Advanced Study (IFIAS) within the framework of their project, "Rethinking Economic Theory." Financial support in the final phases of the project was also provided by the Maastricht Economic Research Institute on Innovation and Technology (MERIT) and a grant from the Dutch Ministry of Economic Affairs.

The project began with an informal meeting of potential authors in Venice in 1986. First drafts of most of the final contributions were discussed by the authors at a workshop in Lewes, England, in October 1986. In May 1987 a second conference was organized in Maastricht, where an enlarged 
circle of authors presented revised versions of their contributions. The book represented a systematic critique of orthodox economic theory for not considering the fundamental role and special character of technical change. ${ }^{11}$ The origin-story behind the NIS section in the anthology (comprising four chapters) is recounted by Lundvall:

What happened there was we had many different chapters that were to be organized according to some principle. But then everything broke down. . .

I saw [this situation as an] opportunity and I said to Christopher [Freeman] and Dick Nelson, 'why don't we make a section with four contributions on national systems of innovation?' So there are four contributions [in that section]. I think that was important because then suddenly you had a book where you had four chapters which were about something people never heard about, that were [by] well known people like Christopher Freeman and Dick Nelson. (Lundvall interview, 20 Oct 03). ${ }^{12}$

In the academic realm, there is a gracious rivalry between Lundvall and Freeman, with each giving credit for the introduction of the NIS concept to the other. While it is often observed that the concept of 'national innovation systems' was first introduced in academic circles by Freeman in 1987 in his book on Japan, Lundvall in fact used the concept 'innovation systems' in 1985 in a booklet on user-producer relations published at Aalborg University (Lundvall 1985)—but without the adjective 'national' added to it. In this booklet, Lundvall provided theoretical arguments and empirical illustrations of user-producer interactions. One main purpose of this booklet was to criticize

\footnotetext{
${ }^{11}$ Almost all of the chapter authors in the book came to the conclusion that no analysis of change that ignored the fundamental role and special character of technical change, even in the very short run, can be valid.

12 The four authors with their chapters are Richard Nelson, "Institutions supporting technical change in the United States," pp.312-329; Christopher Freeman, "Japan: a new national innovation system?" pp.330-348; Bengt-Åke Lundvall, "Innovation as an interactive process: from user-producer interaction to the national innovation system," pp.349-369; Pavel Pelikan, "Can the innovation system of capitalism be outperformed?" pp.370-398. The preface to this section comprising the four chapters, entitled "National Systems of Innovation," is provided by Richard Nelson, pp.309-311.
} 
microeconomics and transaction cost theory and the desire to establish a micro-foundation of innovation systems. Lundvall followed this booklet with his 1992 book, National Systems of Innovation: Towards a Theory of Innovation and Interactive Learning, which explained in greater depth many of his earlier ideas. $^{13}$

Freeman's usage of the concept in explaining national differences between economies, particularly with reference to Japan, was the first widely published use of the concept. Freeman formally introduced the innovation system concept to the literature in Technology, Policy, and Economic Performance: Lessons from Japan (1987), in connection with his analysis of the institutional reasons for the 'developmental gap,' that is, differences in the rates of economic growth among nations

Preceding both these developments, however, was the first use of the terminology in written form by Christopher Freeman in August 1982 in a paper titled, 'Technological Infrastructure and International Competitiveness,' which was presented at the OECD's expert group on Science, Technology and Competitiveness, but which went unpublished at the time. Freeman was working then as an advisor to the OECD ad hoc group on science, technology, and competitiveness, chaired by John Ingram. In a paper presented to the group, Freeman described in detail Friedrich List's advice to Germany on catching up with the UK, staunchly defended Listian economics, and also described why qualitative, history-friendly (indeed historicallydeterministic) economic analyses have a place in economic thinking. In the

\footnotetext{
${ }^{13}$ Lundvall openly asserts that he was not the founder of the idea. At a conference in 2001, however, he did not refute a suggestion that an audience member put to him that if he (Lundvall) was not the 'Charles Babbage' of the NIS concept, then he was certainly its 'Bill Gates.' The computer analogy stems from a paper that Lundvall presented to describe the history of the NIS concept at the 2001 'Nelson and Winter DRUID Summer Conference' held at the Aalborg Conference Center, Aalborg, Denmark, June 12-15, 2001. The paper was coauthored with Björn Johnson, Esben Sloth Andersen and Bent Dalum.
} 
paper, Freeman rather casually mentions the 'national innovation system' concept when discussing the role of 'creation' in technological innovation:

Sometimes, the term 'creativity' is reserved for those abilities of the scientist, which lead to new discoveries or of the artist, which lead to new works of art. These kinds of creativity are important for innovation too. But when we are considering national innovation systems (as opposed to global civilization and the world economy) then at least in the past they have not been so central to innovative success as those types of creativity which are characteristic of the engineer in the work of invention and design and of the entrepreneur (italics in original; Freeman 1982: 9).

Interestingly, the paper was perceived to be too provocative by the OECD ad hoc group and it was not published: "[T]he chairman of the group said only a certain number of people can read this paper because it will cause too much trouble" (Chesnais interview, 29 Oct 03). The "trouble" Chesnais is referring to is the prospect that Freeman had identified a role in the process of technological change to be played by factors outside of the classical neoclassical framework. Listian economics is qualitative in nature, adopts history-friendly analysis—which Freeman is in general agreement with—and considers a wide range of factors in analyzing the innovative process (in other words, the wider 'system' is considered). It was because Freeman introduced these ideas in such depth and with such enthusiasm that his ideas were considered by the OECD group to be too challenging. It has only recently appeared in published form (Freeman 2004), with a foreword by Lundvall (Lundvall 2004), 22 years after originally being presented. In his foreword, Lundvall, too, refers to Freeman's use as the first instance where the NIS concept was used.

Among several of the chief proponents of the NIS concept to have taken up roles in policymaking, Lundvall himself worked as the Deputy 
Director of the DSTI at the OECD from 1992 to 1995 . Even before Lundvall assumed this post, however, the NIS concept had been used in an OECD publication (1992). In particular, there was a major initiative whose work began towards the end of the 1980s under the OECD's 'Technology/Economy Programme' (TEP). The TEP was launched in 1988 to help integrate science and technology policies into other aspects of government policy, particularly economic, social, industrial, energy, education, and manpower policies. From within this program, an important publication entitled "Technology and the Economy: The Key Relationships" emerged in 1992. "A core element of the report is that innovation is a kind of interactive process . . . and this was a major theme" that made it stand out (Lundvall interview, 20 Oct 03). Chesnais concurs on this point when he states, "in that [TEP report] I coordinated, we really did everything to muster all the possible intellectual approaches to say that [building] nations and societies-societies are people and institutions. Technological accumulation is a long and very difficult process, and market forces can disrupt and destroy them extraordinarily quickly" (Chesnais interview, 29 Oct 03).

To a degree, this uncertainty about the origins of the NIS concept is a function of interconnections between the academic and policymaking realms in which the individuals were most involved. My research shows that it emerged concurrently in both the academic and policy fields, facilitated by the overlap of academics at the OECD (where its early development in the policy domain was most pronounced). Freeman worked as a consultant to the OECD in the 1980s, Lundvall was the Deputy Director of the DSTI in the OECD from 1992-1995 (he was the Danish delegate at, and advisor to, the DSTI even before this period), and Smith also worked as an advisor to the OECD in the late $1980 \mathrm{~s}^{14}$ Furthermore, many of the key players in the

\footnotetext{
${ }^{14}$ Lundvall nevertheless states that, by the time he became Deputy Director at the DSTI, "the innovation system approach had been taken aboard already . . . and I actually made extra
} 
development of the NIS concept, such as Chesnais, Lundvall, and Freeman, met with one another frequently at professional conferences and meetings during the time of the concept's inception. Such meetings were an extension of their joint work at the OECD and their independent academic work in the innovation systems area.

Thus the main actors promoting the concept occupied dual roles (in academic and policymaking activities). We can hypothesize that in their work these actors deployed two sets of rhetoric depending on the hats they were wearing or the positions they filled at a given time. In this way, these skilled actors were able to take advantage of the looseness and ambiguity associated with the NIS concept (discussed below) to enhance its appeal to either audience depending on the purpose they were trying to achieve. Given that the NIS concept can be interpreted flexibly and therefore fit comfortably in two distinct spheres, the actors were (and are) able to negotiate seamlessly between theory and application.

The concept of a boundary object helps to explain how the main proponents were able to exploit their dual roles in academia and policymaking to promote the NIS concept. ${ }^{15}$ One key feature of the concept of boundary object is the idea that the objects straddle two or more communities of practice. In the case of the NIS concept, there are two distinct communities which the approach has to straddle: policymakers and academics. Further, in order to be considered a boundary object, the NIS approach must be able to

\footnotetext{
efforts not to be too much married to it, because I didn't want to undermine its position" (Lundvall interview, 20 Oct 03). Upon further questioning, Lundvall explained that as a champion of the NIS concept going into the OECD, his support for it would have seemed blindly prejudiced in favor of its further promotion, and he wished to avoid such a situation. ${ }^{15}$ The concept of a boundary object was introduced by Susan Leigh Star and James Griesemer (1989). Geoffrey Bowker and Star (1999) elaborate on the 'boundary object' concept by defining it as follows: "Boundary objects are those objects that both inhabit several communities of practice and satisfy the informational requirements of each of them. Boundary objects are thus both plastic enough to adapt to local needs and constraints of the several parties employing them, yet robust enough to maintain a common identity across the sites ... The creation and management of boundary objects is a key process in developing and maintaining coherence across intersecting communities" (Bowker and Star 1999: 297)
} 
adapt to the local needs of these two communities while maintaining a common identity across them.

Miettinen's work on NIS argues that the NIS concept is analogous to a boundary object in that it "permit[s] partial agreement in the usage of a term, thus allowing the participants from different collectives to maintain their original cultures" (Miettinen 2002: 19). I agree with this statement, and would add that the NIS concept had the advantage of proponents who inhabited the academic and policy realms, thereby easing the concept's movement between the two worlds.

Setting aside uncertainty as to whether the concept emerged from academia or policymaking (taking the OECD to be a policy-oriented body) we can easily pinpoint the first use of the concept for the purpose of providing a concept for making country-level policy. The first notable, widespread, and significant instance of a country's adopting the concept was Finland in 1992 (Vuori and Vuorinen 1994; Miettinen 2002). In Finland, the NIS concept underpinned three important reviews conducted by the Science and Technology Policy Council in 1993, 1996, and 2000. The 1993 review was especially important, as it was produced when Finland was in the midst of a severe economic recession. ${ }^{16}$ In the 1993 review, the NIS concept was heralded as part and parcel of the country's developmental and recovery strategy. ${ }^{17}$

\footnotetext{
${ }^{16}$ Real GDP dropped about 14 percent from 1990 to 1993, and unemployment rose from 3 percent in 1990 to almost 20 percent in 1994. In terms of many other indicators, the economic crisis Finland suffered during this period was more severe than the depression of the 1930s. ${ }^{17}$ Policies that responded to the NIS concept and helped to haul Finland out of recession included increasing Finland's competitiveness based on knowledge and skills by developing knowledge-intensive fields that center around technologies such as information technology, material science, and biotech; building Finland's NIS by immediately investing in research and development as well as education (since the outcome of these activities appear only after a lag of several years); improving the internal efficiency of institutions that constitute the NIS by systematically evaluating the impacts of policy measures on the NIS; and increasing cooperation and interaction among the components of the system (Miettenen 2002: 69-72).
} 


\subsection{The NIS Concept as a Refutation of the Neoclassical Economics Approach to the Study of Innovation}

It would be difficult to overemphasize the extent to which the NIS concept originated as part of a direct attack on modern mainstream economics. Even though by the 1960s neoclassical growth models had begun to consider the effect of technical progress on growth, this body of work was still marginal in the broader economics literature. Aside from the small group of economists interested in pursuing 'Growth Accounting' in the 1960s, economics was largely dominated by scholars engaged in formal modeling of general equilibrium, in parallel with—although on a separate trajectory from-growth in econometrics; these two streams of work continued their ascent despite the identification of a 'residual' ascribed to 'technical change' by Solow in $1957 .{ }^{18}$ With the backing of influential individuals such as Milton Friedman, Frank Knight, Henry Simons (all economists associated with the 'Chicago School') and the Austrian Friedrich Hayek, neoclassical economics drew further strength from libertarians. ${ }^{19}$ Libertarians emphasize the central importance of personal freedom in economic and political affairs, remind us of the accomplishments of the market mechanism, and warn us of the penalties falling upon any society that ignores the market's guiding hand. Transforming economics into a "mathematical science," these economists argue that the role of government in the economic arena should therefore be minimal (Weintraub 2002).

Neoclassical economic thought permeated the policy sphere in the 1980s. This policymaking climate mirrored the academic climate and it, too,

\footnotetext{
${ }^{18}$ Econometrics, unlike formal modeling of general equilibrium, employed at the time large datasets and had direct policy applications.

${ }_{19}$ The term "Chicago School" is associated with a particular brand of economics that adheres strictly to neoclassical price theory in its economic analysis and 'free market' libertarianism in much of its policy work.
} 
affected the development of the NIS concept in policymaking. Chesnais (exprincipal administrator of the science and technology policy division in the DSTI at the OECD) articulates this point well:

We were in the 1980s, we were in a very open economy, moving towards globalization, we sort of sensed it, but the processes weren't very clear. We still used the term 'internationalization,' and very many countries had balance-oftrade problems, and trade competition had started becoming very strong, and they, in the OECD, developed two strands of thinking and policy recommendations.

One, which based itself on classical, neoclassical, orthodox trade theory, comparative advantages and costs, and whose main policy recommendations were to bring wage costs down; and, in the economic department, they published a study which-Indicator of Competitiveness-was in fact a revamped version of the level of wages as an indicator.

And I and the group I had around me [at the OECD's DSTI] said competitiveness is basically a holistic social phenomenon, it's based on a whole set of things which we ended up by dubbing 'structural competitiveness.' And the first time Christopher Freeman brought the concept of national systems up was in a paper he prepared for this working group at the OECD on science, technology, and competitiveness.

We were fighting neo-liberalism. We were doing this at the start of the Uruguay round [of trade talks]. We were doing this in spite of Margaret Thatcher and Ronald Reagan so we were saying 'national' when the trend was already saying governments must bow out . . the importance was political, really, and it became one of the rallying flags for people who continued to say that national economic systems are not just markets, there are institutions, there are systemic relations, there are linkages (my italics; Chesnais interview, 29 Oct 03).

The growing reliance in mainstream economics on models and tools rooted in the neoclassical tradition, in addition to the peripheral role advocated for governments, marginalized those who felt that economics was becoming detached from the realities of the contemporary world. At the same time, the continued rise of (mainstream) neoclassical economics helped shift the focus 
away from long-run economic growth toward conditions of economic equilibrium. Garnering their inspiration from Schumpeter, and holding up List as one intellectual forebear, Freeman and Lundvall represented the reawakening of an institutionalist 'school of thought' within innovation studies under the NIS banner.

In his later writings, from The Theory of Economic Development (1934) to Capitalism, Socialism, and Democracy (1962), Schumpeter argued against the prevailing trend among economists to define the core subject matter of the discipline as firm behavior, prices, and quantities under conditions of equilibrium. Schumpeter was clear that the most important feature of capitalism was that it was an engine of economic progress (Nelson 2004). Taking this as their cue, both Freeman and Lundvall said that they felt dissatisfied with the lack of attention mainstream economic theories accorded to knowledge, technology, and technical change. Influenced by Schumpeter's analysis, Freeman, Lundvall, and other contemporary economists studying technological advance around the 1970s and 1980s agreed that innovation, technological or otherwise, could not be understood within the confines of a theory that assumed stable equilibrium.

In this way, the NIS concept has roots in the perceived inadequacy of neoclassical economic thought when treating technology; the discontent felt by key individuals is what fueled the new field. ${ }^{20}$ Here is Lundvall questioning the wider neoclassical assumptions: "[M]y own motivation for doing this [NIS work] is dissatisfaction with standard economics." He elaborates:

\footnotetext{
${ }^{20}$ To be sure, innovation studies scholars acknowledge that 'New Growth Theory' or 'Endogenous Growth Theory' (cf. Romer 1986, 1990; Grossman and Helpman 1991; Aghion and Howitt 1992) incorporates more-realistic assumptions into neo-classical models, but they complain that the basic premises and features of neoclassical economics are kept largely intact. Endogenous growth theory, argue evolutionary economists, is an effort to stretch an economic theory concerned with an equilibrium configuration of quantities and prices to deal with the phenomena of continuing economic growth. To do this requires augmenting the production function part of that theory so as to admit continuing technological advance, but the basic features of the theory are unchanged (Nelson 2004).
} 
I have always been annoyed by how, in spite of its limited relevance and validity, neo-classical economics has pursued the pretentious intention to colonize all thinking about the economy. One important motivation for my interest in innovation and innovation systems is actually that when you focus on innovation it becomes absolutely clear that the neoclassical assumption about agents making choices between well-defined alternatives cannot apply. Any true innovation involves uncertainty since the outcome per definition is unknown. A focus on interactive learning in the context of innovation helps you also to understand why 'economics' cannot stand alone when it comes to explaining economic development and why interdisciplinary approaches are necessary. These are soft points in the neo-classical schemes of thought. (Lundvall interview, 20 Oct 03). ${ }^{21}$

In a similar spirit Metcalfe asks, rhetorically, "How does an economist think about knowledge and information?" and answers, "first of all, they don't understand the distinction between the two very clearly! They think of them in terms of being very peculiar objects, entities, which don't fill the normal canons of an economic good. So there are all sorts of reasons why you cannot expect markets to do the right thing; that there will therefore be very, very big differences between the private and social return to investment in knowledge" (Metcalfe interview, 23 Oct 03).

In describing why the term 'national innovation system' was adopted, Freeman recalls, correspondingly, "I thought it would be a good idea to use the expression because it would emphasize this weakness of an economic system that had left out innovation in much economics literature" (my italics; Freeman interview, 24 Oct 03). Freeman continues, "but it shouldn't have been necessary, really. It was only necessary because a lot of neoclassical economics had abandoned the study of innovation, didn't take it seriously,

\footnotetext{
${ }^{21}$ This sense of dissatisfaction is supported by Lundvall's and other NIS proponents' writings, most notably: Lundvall (1998); Freeman (1988); Nelson (1988), and; chapters in Edquist and McKelvey (2000).
} 
and that was why it was important to emphasize it, or re-emphasize it"22 (Freeman interview, 24 Oct 03). ${ }^{23}$

\subsection{Formation of an NIS Epistemic Community}

There are two fruitful ways of analyzing the NIS concept against the competing paradigms of Porter's Diamond Model and Etzkowitz and Leydesdorff's Triple Helix Model. One is to employ ideas that Andrew Abbott (1988, 2001), Richard Whitley $(1983,1984)$, and Roy Weintraub (2002) have contributed to the study of the way disciplines develop and differentiate themselves in establishing 'turf. ${ }^{24}$ These studies explicate the processes through which better and longer established disciplines form, differentiate, and even fracture. While such an approach is useful for studying the development of the NIS concept, a second-and in my opinion more fruitful—way of conducting the analysis is in terms of the notion of 'epistemic communities.' The idea of epistemic communities applies here because it captures the

\footnotetext{
${ }^{22}$ Re-emphasis for the study of innovation was necessary as earlier economists such as Adam Smith, David Ricardo, and Freidrich List did consider innovations central to a much greater extent than did most contemporary economists.

${ }^{23}$ To be sure, the national innovation systems concept was not the only competitor to neoclassical economics for explaining technological growth. Other competing theories and approaches were also vying with the NIS concept (against neoclassical economics as well as the linear model of innovation) at the time of the NIS concept's development. At the very least, these competing theories and models also addressed issues that neoclassical economics failed to consider adequately. These competitors to the NIS concept included Michael Porter's 'Cluster' or 'Diamond' model of thinking, published in The Competitive Advantage of Nations in 1990, the 'Triple-Helix Model' of university-industry-government interactions developed mainly by Henry Etzkowitz and Loet Leydesdorff $(1997,1998,2000)$, and the 'New Production of Knowledge' approach of Gibbons et al. (1994).

${ }^{24}$ Abbott (1988) analyzes the process by which occupations gain, maintain, adjust, and sometimes lose their ability to control particular tasks in competition with other occupations. In a more recent publication, Abbott (2001) maps patterns of social science research during the last century and lays down a set of principles by which it is organized —or, he would argue, by which the research in fact seems to organize itself. Whitley's comparative study of how different scientific fields are organized builds on a static type of analysis that is adequate for understanding structural questions about a field at a specific time and why certain structures are observed in specific environments. According to Whitley $(1983,1984)$, it is possible to identify some of the most important features of scientific disciplines by analyzing them as 'reputational organizations.'
} 
process by which the NIS concept is co-constructed in the political and scientific arenas.

As scholars and policymakers involved in the NIS concept sought to challenge the dominance of neoclassical economics, especially in relation to the issue of technical change, they formed such an informal network or epistemic community (Haas 1990; Haas 1992; Adler and Haas 1992). Here, the epistemic community is created by the informal associations of practitioners involved in the innovation studies field who developed it in an interdisciplinary manner, so as to study relationships among technological, economic, organizational, and institutional changes.

Informal networks —in the form of friendly relationships among researchers and decision-makers-are as important in linking research and policy, and effecting policy change, as formal structures. An epistemic community, writes Ernst Haas (1990), consists of colleagues who share a similar approach or position on an issue. By attending the same conferences, workshops, and meetings, working together at the OECD, and working jointly on book and paper projects, members of the NIS epistemic community maintain contact with each other across their various locations and fields, thus creating valuable channels for information flow. ${ }^{25}$ These informal forums can be used to discuss and pass on alternative perspectives on current issues, and if the network comprises prominent and respected individuals-in the way the NIS network comprised researchers who occupied influential positions simultaneously in academia and policymaking_pronouncements from these networks can force policymakers to engage with an issue, just as the NIS concept did. Ernst Haas (1990) concludes that such an epistemic community

\footnotetext{
${ }^{25}$ Witness, for example, Freeman's and Lundvall's cooperation, as manifested in Freeman and Lundvall (1988); Lundvall (1993), in Foray and Freeman (1993); and their cooperation in the NIS section of Dosi et al. (1988).
} 
provides a potent means of overturning the conservatism of the old paradigm or school of thought. ${ }^{26}$

Adler and Peter Haas (1992) describe an epistemic community as an international community of researchers and experts whose ideas influence the adoption of public policies. This community exerts its influence primarily by "diffusing ideas and influencing the positions adopted by a range of actors, including domestic and international agencies, government bureaucrats and decision makers" (Adler and Haas 1992: 379), and by acquiring bureaucratic positions within public organizations. According to Peter Haas (1992), epistemic communities can "influence national governments and international organizations by occupying niches in advisory and regulatory bodies. This suggests that the application of consensual knowledge to policymaking depends on the ability of the groups transmitting this knowledge to gain and exercise bureaucratic power" (Haas 1992: 30). My findings (see Section 4.1 above) show that by occupying influential roles in policymaking bodies (notably the OECD) and academia, many of the early proponents of the NIS concept combined to function as a collective epistemic community, thereby forming the power base in both domains that the NIS approach enjoys today. ${ }^{27}$

\footnotetext{
${ }^{26}$ In discussing science policy in global environmental regimes (particularly the work of environmental activists and policymakers), Jasanoff (1996: 187) raises several important questions about the notion of 'epistemic community.' Jasanoff asks: "What accounts for the magnetic power of the 'episteme' that unites epistemic communities? Is the policy project that epistemic communities share distinct from or an outgrowth of the common knowledge base to which they also jointly subscribe? What is the mechanism by which these groups achieve their cognitive authority in the political domain?" The answers to these questions are not straightforward, partly because of ambiguities in the way Adler and Peter Haas have used the term 'epistemic' and partly because of recent theoretical concerns emanating from the field of science and technology studies regarding the nature of knowledge.

${ }^{27}$ Knorr-Cetina (1999) employs the complementary term 'epistemic culture' to characterize the knowledge strategies not captured in textbooks that inform expert practice. The term refers to various techniques for creating and warranting knowledge in different domains. If the knowledge society argument (i.e., that knowledge has become a productive force replacing capital, labor, and natural resources as the central value and wealth-creating factor) is correct (Drucker 1969, Bell 1973, Castells 2000), epistemic communities or cultures need more attention so as to make visible the complex texture of knowledge as practiced in the social spaces of modern institutions
} 
A final, perhaps more concrete, way to illustrate the presence and importance of the NIS epistemic community is to elucidate their numerous informal contacts through major book projects in the NIS field. The coalescing of this informal network for the Dosi et al. (1988) book has already been established above. An additional landmark in the NIS field that helped form the NIS epistemic community is the volume edited by Nelson (1993), National Innovation Systems: A Comparative Analysis. To write the book, the informal network formally met one another five times in the United States and Europe so that all of the individuals involved could discuss chapter drafts. A third milestone anthology in the field, edited by Edquist (1997), is Systems of Innovation: Technologies, Institutions, and Organizations. This book was the outcome of work undertaken by a group set up by Edquist in 1994. This group, which included representatives from variants of the NIS concept, also permitted a continuous dialogue for its participants.

These book projects sufficiently illustrate how the NIS epistemic community was formed through professional relationships linking policymakers and academics in order to effect change in both the academy and policymaking bodies. As a result of this shared approach, these individuals maintained regular and frequent contact to work on the abovementioned book projects, thus creating valuable channels for the flow and exchange of ideas and ways of understanding the NIS concept. Such forums no doubt enabled the discussion of and exchange of alternative perspectives on the NIS approach thereby, in Ernst Haas's (1990) terms, counter-balancing the conservatism of the old paradigm (of the treatment of technological change in neoclassical economics). ${ }^{28}$

\subsection{Flexible Interpretations of the NIS Concept}

\footnotetext{
${ }^{28}$ Less well documented but just as important instances of cooperation and links between the NIS epistemic community occurred through various EU projects. However, at these meetings, there were, naturally, mostly scholars from the EU member countries.
} 
Although the concept of a 'national innovation system' has been in use for the past twenty years, even today it is subject to a remarkable variety of interpretations, making it function as a boundary object. Academics and practitioners embrace varying conceptions of the approach's domain of reference. It is freely acknowledged among the founders of the approach that the concept of "innovation systems means different things for different people" (Lundvall interview, 20 Oct 03). By focusing on debates among the relevant social groups, I am able to reveal the underlying rationales for and outline the effects of flexible interpretations of the NIS concept that result from its status as a boundary object.

These flexible interpretations stem from two features of the NIS concept. First, the approach inspired the ambition among its progenitors to transcend a narrow disciplinary focus; such an ambition naturally complicates consensus-building around a particular definition of the concept as practitioners from distinct disciplines impose their understandings on it. A second source of the flexible interpretations is the state of flux in which the new field of innovation studies finds itself as it seeks to strengthen its multidisciplinary roots.

Because of the possibility of conceptualizing the innovation systems concept at various levels, there is much disagreement among academics and policymakers about whether it is efficacious to identify the 'national' unit as the delimiting criterion of an innovation system as opposed to choosing the regional, sectoral, or technological innovation system as the chief object of study and measurement. There are some (such as Coombs) who say that the 'national' system of innovation concept has run its course and now provides only decreasing returns. As a result new, complementary concepts emphasizing the systemic characteristics of innovation that focus on 
economic domains other than the nation-state have emerged. ${ }^{29}$ Within the academic and policy spheres, the innovation systems concept can take several forms based on distinct criteria of classification: spatial, technological, and industrial, or sectoral. ${ }^{30}$ These concepts have been presented sometimes as alternatives and sometimes as complements to the national innovation system approach. Advocates of the other domains have argued that many interesting interactions in the context of modern innovation cross national borders, particularly in an era of multinational companies. There is therefore no a priori reason, the argument runs, that the national level should be privileged.

Others (such as Freeman) argue, however, that the 'national' domain better accommodates the policy dimension of the concept. As long as nationstates exist as political entities with their own agendas related to innovation, it is useful to work with national systems as analytical objects. This latter group argues further that, even though regional, sectoral, or technological systems often transcend a country's borders, national characteristics and frameworks always have a role to play in shaping the system in question (regardless of the delimiting criterion employed).

If the original ancestry of the concept is traced, within both the academic and policy realms, it is clear that the 'national' criterion was consciously chosen. It was no accident that the original thinkers of innovation systems did not focus on local or microeconomic levels (i.e., on regions or sectors) as later studies do: The NIS concept was introduced explicitly to compete with, indeed to replace, traditional neoclassical macroeconomic

\footnotetext{
${ }^{29}$ See, for example, Breschi and Malerba (1997); Malerba (2004, 2005); Carlsson (1994, 1995, 1996), and; Carlsson and Jacobsson (1997).

${ }^{30}$ In addition to 'national' innovation systems, for example, we can identify 'regional' innovation systems (e.g., many innovative companies are concentrated in Silicon Valley), 'sectoral' innovation systems, (e.g., energy-related industries rely on an industry-specific innovation system); and 'technological' innovation systems (e.g., electronics with applications in a variety of different industries).
} 
(national-level) theory. Innovation studies scholars and policymakers identified gaps in neoclassical economic thinking and proposed the NIS as an alternative that would plug those inadequacies. As Freeman puts it, "most of the people working on innovation systems prefer to work at the micro level and they are a bit frightened still of the strength of the neoclassical paradigm at the macroeconomic level, and I think that's where they have to work. You have to have an attack on the central core of macroeconomic theory. It is happening but not happening enough, not strongly enough argued." ${ }^{31}$ Freeman adds, more avidly, that "the main area [of the NIS approach] that needs to be strengthened is the main core of economic theory, macroeconomic theory, and I think you can't shift the main central core of neoclassical economic theory simply with microeconomic studies" (Freeman interview, 24 Oct 03).

Considering that Freeman himself was, in the late 1930s, a student of Keynes, it is not difficult to understand how this offshoot of the Schumpeterian movement developed intentions to attack neoclassical macroeconomic theory head on. In other words, the national innovation system concept was established with the explicit goal of challenging the analysis of technological change put forward in neoclassical macroeconomics, and this is why Freeman and other original proponents embrace a higher, macro-scale level of aggregation. $^{32}$

\footnotetext{
${ }^{31}$ Here, Freeman's reference to the 'neoclassical paradigm at the macroeconomic level' is to Solow's work on creating a macro-production function from neoclassical elements. He is not referring to Keynesian macroeconomics.

${ }^{32}$ In order to understand Freeman's insistence on working at the macroeconomic level, it is also helpful to keep in mind the hierarchy in economic thought. Leijonhufvud (1981) argues that in economics scholarship, macroeconomic theory occupies the most prestigious position, followed by microeconomic theory and econometrics in turn. Below macro- and microeconomic theory and econometrics lie the subfields of industrial policy, labor economics, development economics, institutional economics/comparative economic systems, and the history of economic thought. This hierarchy, one can speculate, played a role in the choice of an agonistic field
} 


\subsection{Disagreement Surrounding Over-Theorization of the NIS Concept}

Two closely connected disagreements highlight the flexible nature of the NIS concept. The kernel of the first disagreement is whether or not the concept should be more rigorously theoretical. Here, I am able to identify two groups within the NIS research program: one holds that the concept should be more deeply theorized and explained in greater detail in order to make it more precisely applicable (i.e., Edquist, Metcalfe, and Fagerberg), and the other argues that the approach's usefulness is a product of its being 'loose' and 'flexible' (i.e., Smith, Nelson, and McKelvey).

This disagreement, more than any other, is materially important because it has the potential to affect how the NIS concept develops and evolves in the future. At present, researchers and policymakers attach a variety of meanings to the NIS concept and even the originators of the concept operate with varying conceptions of what it means. The idea of how to evaluate a country's competitiveness is, therefore, interpreted flexibly, having different meanings for different actors. There is thus no universal standard that draws the approach together, and no benchmark for the 'correct' way that a country can attain an optimal or ideal system of innovation. Because the controversy remains active, a symmetrical approach to studying this disagreement can generate a useful appreciation of the development of the approach.

As a result of the multiple, shifting interpretations of the NIS concept, sustained, concrete usage of the approach varies. Smith, for example, remarks that the NIS approach "is talked about much more than it is actually applied" (Smith interview, 13 Oct 03). Edquist, commenting on research he conducted, claims, "I went through all the OECD studies [on the NIS concept] and it is meters of material, and [the concept] is not concretely used! It is not 
operationalized in a concrete and consistent manner, not used in the way of using this framework to formulate conjectures or hypotheses and test them in an empirical way" (Edquist interview, 21 Oct 03). McKelvey concurs in stating that the NIS concept "doesn't always answer a research question" and that "it may be useful for some purposes, but you have to make a much sharper research question." As a result, she concludes that "although it was something I was familiar with and involved in . . I d didn't always use it directly in relation to my interests in innovation processes." ${ }^{33}$ To do so, McKelvey believes, "theories from other dimensions infuse the innovation concept with meaning, as demonstrated in [McKelvey 1996]." (McKelvey interview, 18 Oct 03).

In policymaking, Guinet, the present principal administrator of the science and technology policy division in the DSTI at the OECD, remarks along similar lines when he states that "this approach was always useful just to locate one project and to organize synergies between the projects; for identifying priorities for research works which would have direct relevance for government policy." More explicitly, he notes that "this framework in its purest form is not that complicated . . on a map_-it is like a GIS [Geographic Information System] — so you know where you are driving . . . it is for that reason only a navigation tool" (Guinet interview, 28 Oct 03).

Despite its not having been effectively operationalized, Guinet nevertheless considers the NIS tool to be valuable because "it helps identify certain key linkages between the subject you are dealing with and other broader subjects. And this is very important from an analytical perspective and from a policy perspective. From a policy perspective, it helps legitimize the importance of different aspects which are important but underestimated. [For example], there is a ministry of finance which sometimes thinks that,

\footnotetext{
${ }^{33}$ McKelvey believes 'innovation processes' are key to understanding economic phenomena.
} 
'yes,' why bother about the innovation system, and why be so excited about the public research priority, or reform the way public research bodies are managed and financed? But the NIS framework helps to tell a convincing story about the fact that this subject is clearly linked" (Guinet interview, 28 Oct 03).

Partly because several practitioners in the NIS field are unhappy that the concept is not completely and uniformly operationalizable, and partly in an effort to encourage the field to converge on a uniform interpretation of the concept, Edquist is engaged in a project aimed at making the concept less "fuzzy" and "diffuse" (Edquist and Hoemmen 2004) by removing the "conceptual ambiguities" contained in it (Edquist interview, 21 Oct 03) ${ }^{34}$ Edquist utilizes his alliances and networks in the field in order to justify his project. His major strategy in the pursuit of his goal is a project sponsored by the European Science Foundation, "National Innovation Systems of Ten Small Economies," covering Denmark, Finland, Hong Kong, Ireland, Korea, Sweden, The Netherlands, Norway, Singapore and Taiwan. This study not only adopts the 'national' delimiting criterion and functions on an explicitly national level but, more importantly, it operationalizes the concept according to a set of uniform criteria to study all ten economies' innovation systems. In fact, Edquist has personally taken (and continues to take) steps to ensure that the study does not, for example, fall into the other analytical frames of regions, sectors, or technologies. ${ }^{35}$ Furthermore, Edquist (and his co-author Leif Hoemmen) have provided participants in the project with a 118-page (single-spaced) document that explains in minute detail the guidelines which he expects contributors to follow (Edquist and Hoemmen 2004). These

\footnotetext{
${ }^{34}$ One such conceptual ambiguity afflicts the term 'institution,' which is used in different senses by different authors. Sometimes the word means different kinds of organizations or 'players' in the system (see, for example, Nelson and Rosenberg 1993). Yet at other times, the term refers to laws, routines, and other 'rules of the game' (see, for example, Lundvall 1992).

${ }^{35}$ Personal observation at the Taipei Workshop for this project, 26-28 November 2003.
} 
guidelines are meant to operationalize the NIS according to Edquist's approach.

Edquist explains that, "in this [ten-] country project now, we are trying to formulate a comparative framework for addressing the national innovation system of the countries in the same way, in all the economies, not repeating the Nelson [1993] way of doing it [where R\&D systems were outlined according to the preferences of each of the chapter authors, not according to any standardized criteria], but having a profoundly comparative framework. We want to analyze these systems, how do they operate, why are some of them so much more innovative than others and so on and are they more innovative than others, and how do you measure that, trying to use this approach directly as an analytical tool to handle empirical information and data" (Edquist interview, 21 Oct 03).

In a similar vein, Metcalfe explains what he thinks needs to be done about the under-theorized nature of the NIS concept: "I think we do need to spend a hell of a lot more time theorizing. That's why other perspectives are important in this, I think; by taking broader insights from evolutionary thinking, from social constructivism, from institutionalism and so on, and actually applying them to concrete case studies" (Metcalfe interview, 23 Oct 03). Interestingly, Edquist invokes science in justifying and legitimizing his project for making the approach more 'rigorous.' When discussing the sloppiness of the approach, he states that "maybe people appreciate that [NIS] is so fuzzy, maybe some people inside realize this and therefore they don't want to make it more scientific" (my italics; Edquist interview, 21 Oct 03). In other words, in this view, the weakness of those who do not wish to theorize the concept more deeply is that they are being 'unscientific' and insufficiently 'analytical.' In order to gain respectability in the academic 
universe, providing a theoretical basis for the concept would, in Edquist's view, enable it to grow because of new rigor and certainty.

On the other hand, arguments and writings by scholars such as Smith, Nelson, and even, to a lesser extent, Lundvall, aim to maintain the suppleness of the NIS concept. Smith, for example, complains that moves such as Edquist's "seem to be a bit over-theorizing" (Smith interview, 13 Oct 03). Nevertheless, Smith concedes that there is a challenge in pushing the approach forward, and this involves asking which institutions and institutional structures are important and why, and researching those elements in greater detail. Nelson understands Edquist's project to more deeply theorize the concept as "being on the road to something, but it is not clear that that's a particularly good route to follow," although he ends with, "I'd be happy to have him try!" (Nelson interview, 10 Nov 03). Similarly, Lundvall thinks it is important "not to over-do it" (Lundvall interview, 20 Oct 03).

Furthermore, by questioning the role of science and scientific theory within social science, Lundvall justifies the nebulous nature of the approach. Asks Lundvall, "is [social science] something which is very similar to actual scientific theory or especially mechanical physics within natural science or is it different?" He answers that "it is something radically different and those who criticize social theory for not being very similar to natural science will always either become very inconsistent when they come with their pretensions because they will never be fulfilled or alternatively they will be very disappointed" (Lundvall interview, 20 Oct 03). In a similar vein, Lundvall argues that the diffuse nature of the NIS concept "has to do with both kinds of social science. You would think it is useful both in terms of understanding what is going on and in terms of doing something about it. And for me, that kind of theory must have a very strong historical dimension . . . some people who want to abstract from both dimensions of space and time [miss] that the 
system of innovation has different meanings in different historical periods and different locations" (Lundvall interview, 20 Oct 03).

Simultaneously, Lundvall continues to marshal his resources to disseminate his (loose and supple) version of the NIS approach in, for example, a recently published book on African innovation systems (Muchie, Gammeltoft, and Lundvall 2003), a forthcoming book on Asian innovation systems (Lundvall et al. 2006 [forthcoming]), and the 'Globelics' and 'Asialics' initiatives, to name but a few. The Global Network for Economics of Learning, Innovation, and Competence Building Systems (GLOBELICS) is a worldwide collection of scholars who apply the concept of learning, innovation, and competence-building systems (LICS) as their concept. The network, spearheaded by Lundvall, is especially dedicated to the strengthening of "learning, innovation, and competence building systems" in countries in the 'South' (broadly conceived). Asialics is the Asian chapter of Globelics. Asialics aims at creating an Asia-wide network of scholars and policymakers whose concept features the common use of the concepts of national innovation systems and competence building. There is even a Latin American chapter, 'Lalics,' and an African chapter, 'Africalics. ${ }^{\text {,36 }}$

In other words, parallel to Edquist's efforts, Lundvall is deploying his own networks and alliances to the full in order to further the NIS concept as he thinks it should be developed. One possible way to understand Lundvall's ambition vis-à-vis Edquist's is that the former is less interested in creating an academic 'asset' out of the NIS concept (this could quite possibly be related to his experience working in the OECD), whereas the latter is resting his academic future on the approach's continued academic development. As a major global policy vehicle, the OECD is less interested in theory for the sake of theory than are the academics. Conversely, the OECD is more interested in

\footnotetext{
${ }^{36}$ For more information on these sub-chapters and on Globelics, see: http://www.globelics.org (accessed 15 September 2004)
} 
end results or the "bottom line" as manifested in terms of concrete policy recommendations for its member countries. For this reason, if we were to generalize, we could say that the overall rigor of the NIS concept is less important in the policymaking sphere than in the academic sphere. The academic and policy domains act as qualitatively different forms of 'customers' or 'users' having different requirements with respect to the precision of the NIS concept. We can understand Edquist's and Lundvall's attempts to engineer the concept more or less in terms of its effectiveness in serving a particular 'customer base' or 'user group.'37

At a more general level, this exchange demonstrates how different actors employ different repertoires and resources to justify their respective positions. On the one hand, Edquist is undertaking a major comparative study and invoking the scientific principle partly to unify the meaning of the concept. On the other hand, Lundvall questions the value of taking a rigorously scientific approach in social science, defending a broader attitude and conceiving of the NIS concept as a loose umbrella approach. ${ }^{38}$

\footnotetext{
${ }^{37}$ The issue of users or user groups in relation to technology has been studied in a variety of fields, from S\&TS (Woolgar 1991; Oudshoorn and Pinch 2003), innovation studies (von Hippel 1976, 1988; Coombs 2001), and feminist studies (Cowan 1987; Wajcman 1991), to cultural and media studies (Bordieu 1984). Oudshoorn and Pinch (2003) provide an excellent overview of such work in their introduction, and the individual chapters in the same book address the issue of how users are defined and by whom and the lessons to be drawn from a renewed focus on users in technologically mediated societies.

${ }^{38}$ To be sure, this debate surrounding deeper theorization of terms is not unique to the NIS concept; similar debates occur across the social sciences. We see this even in the S\&TS discipline, in the debate over the use of the term 'paradigm.' The philosopher Margaret Masterman (1970) criticizes Thomas Kuhn (1962) for his use of the word 'paradigm' because it connotes 22 different meanings. This criticism was countered by Collins and Pinch, who in their book Frames of Meaning (1982) argue that the beauty of the term rests precisely in its flexibility. Collins and Pinch argue further that loose and flexible terms are exactly what are needed in the social sciences (as opposed to the natural sciences, where precise, discrete, and measurable definitions are the norm) so that they can be applied widely. Furthermore, Lynch's analysis of constructivism can also be applied to understand this debate. Lynch (1998) provides a constructivist development of the idea of 'construction,' concluding that, not only do diverse constituencies latch on to the word 'construction' for different reasons, but the word is also a pivotal term because of the confusion that it ultimately tends to engender, as "it provides an initial hook that captivates adherents, encouraging them to invest their theoretical, methodological and political hopes in an academic approach or movement." But, Lynch continues, it can be confusing when adherents try to replace the eclectic surface affinity that fosters the term's success in the first place "with something deeper and more coherent" (Lynch 1998: 29). In its appeal to different social groups, the NIS concept has
} 


\subsection{Disagreement on the Presence of an NIS in all Countries}

A second disagreement related to the flexible interpretations of the NIS concept asks whether every country in the world possesses a national innovation system. Again, depending on the definition of the concept adopted, different answers are proposed. My respondents fall into two groups, with one insisting that every country has an innovation system and the other arguing on various grounds that the question turns on the presence of certain conditions. Jacobsson, when asked whether all countries have or can use the innovation systems concept, replies emphatically, "why not?" (Jacobsson interview, 17 Oct 03). Freeman also agrees that every country has an innovation system when he claims, "some [NISs] are more effective, some are not. Some are embryonic, some are almost non-existent, but they have something" (Freeman interview, 24 Oct 03). Malerba concurs, saying that "every country has a system. Every country has a system of generation and diffusion of technology. Maybe Tanzania has a system for diffusing technology, maybe it doesn't generate, but anyway ..." (Malerba interview, 27 Oct 03). In this group, a national innovation system refers to the assemblage of policy and market elements that constitutes innovative capability.

Smith, on the other hand, falls into the second category as he states, "[The NIS concept] needs a certain socioeconomic dimension. It needs some real structure before it really gets to become useful." On the specific point of developing countries' employing the concept, Smith claims, "I think there is a serious issue in many developing countries about governments and political organization. For me, it is more of a question of, are there political forces who are prepared to back development strategies in the country?" (Smith 
interview, 13 Oct 03). For this group of individuals, calling a system an NIS presupposes an inherent judgment regarding the quality of institutions and policy. Only if the institutions and organizations working towards development have progressed sufficiently (i.e., beyond dealing with issues of basic poverty and illiteracy) can they be deemed constituent elements of a broader innovation system.

Again, this disagreement is largely a function of the various definitions of an innovation system or indeed of 'innovation' that are embraced by different individuals. Even the earliest champions, those who worked on the development of the NIS concept at almost the same time, part company on what seems to be a fundamental point. If, by an innovation system, one thinks of a system for generating and diffusing new technologies, then it is conceivable that every country has such a system, even if it is weak or low in capacity. According to this definition, even if a country possesses a very weak system for generating "new" technologies, its system for diffusing technologies from abroad (the Internet, for example) must still be present. If, on the other hand, we think of an innovation system in narrow terms as solely a mechanism for generating new technologies, then it is likely that many countries do not have an NIS.

\subsection{Importance of the Wider Global Geo-Political Context}

I now consider the wider socio-economic and global geo-political context in which the NIS concept developed in order to relate the content of the NIS concept to the wider sociopolitical milieu. The NIS concept was coconstructed within the wider sociopolitical environment. This wider context has affected the meaning ascribed to the NIS concept by the social groups making use of it. 
The approach did not emerge at just any moment in history, but precisely when economic globalization was accelerating during the 1980s and when international competition among companies was intensifying. In particular, Japan was emerging as a new global economic powerhouse, dominating a variety of industrial sectors and moving up through the league tables as measured by gross national product. This explains Freeman's interest in studying Japan when he formally introduced the NIS concept to the literature in $1987 .{ }^{39}$ Even prior to the publication of his 1987 book on Japan's increasing economic dominance, however, Freeman was acutely influenced by Japan's economic ascent. This is evident in his OECD 1982 paper, in which he devoted an entire section to Japanese competition, attributing Japan's success to "Iong-term policies pursued over many decades, rather than to any short-term manipulation of currency exchange rates, or exploitation of relative factor-cost advantages" (Freeman 1982: 21).

Amid this worldwide climate of fear of a 'Japanese threat' there were calls for countries, including even the United States federal government, to learn from the Japanese example, particularly that of the Japanese Ministry of International Trade and Industry (MITI), which was spearheading the coordination of innovative activity in Japan throughout the 1970s and 1980s in order to promote and facilitate innovative activity. ${ }^{40,41}$ In other words, the idea was to respond to the threat from Japan by being more like Japan.

Given the perceived threat to the industrialized world posed by Japan, it is, however, interesting to note that Europe-particularly Scandinavia-was swifter in its up-take of the NIS concept as compared with the United States.

\footnotetext{
${ }^{39}$ For additional literature that was essentially a reaction to the Japanese economic ascent, see, for example, Vogel (1979) and Johnson (1982).

${ }^{40}$ See, for example, Branscomb 1987, 1993; Brooks 1993; Samuels 1994.

${ }^{41}$ Notably, the scholars forwarding the argument for a larger role for government were associated with the Democratic Party, whereas scholars more generally affiliated with the Republican Party were of the view that governments could not (and should not) 'pick winners' in the economy.
} 
One reason for this may have been the more acute sense of a 'threat' felt by smaller, highly international and globally connected economies that are characteristic of Scandinavia and Northern Europe. Such smaller countries are more reliant on external demand trends as well as shifts in global production and consumption patterns. ${ }^{42}$

In this newly emerging economic context, companies' competitiveness grew more dependent on the ability to apply new knowledge and technology to products and production processes. Companies had to adapt to rapidly changing market conditions or take the lead by innovating their products and processes in a world where technological developments were taking (and continue to take) place at an ever-increasing rate. It became increasingly difficult for individual companies to produce knowledge they needed themselves. Consequently, to succeed in the innovation process, companies more than ever needed complementary knowledge and expertise developed by other companies, universities, and private and public laboratories. In other words, the acceleration of the rate of production of knowledge that accompanied economic globalization required that companies intensify their participation in knowledge production networks to sustain their competitiveness (Albert 2001).

These sets of company-specific as well as country-specific pressures shed light on the importance of the wider context in the development of the

\footnotetext{
${ }^{42}$ Another related reason was that, given the breadth and depth of the American economy, it was buffered from the Japanese 'threat' for a relatively longer period as compared with its smaller European counterparts. Indeed, McKelvey notes this point when she says, "in some sense, had the United States' sense of crisis towards Japan gone on a little bit longer, they [the United States] may have started looking around a little more" (McKelvey interview, 18 Oct 03). Coombs concurs on this point when he states, "I think it would have been different if the NIS had [been more popular] at exactly the height of the point when America was at its most un-self-confident vis-à-vis the Japanese. If [NIS] had been put forward when the American vehicle and electronics industry were really suffering very badly at the hands of the Japanese, and the Japanese economy was at a point where it wasn't ridiculous to speak about it overtaking the American economy within 10 years or something - we're talking about the late 1970s, early 1980s here-it [NIS] would certainly have had more bite in the US. But then the [Japanese] debate started to recede by the time the NIS really took off" (Coombs interview, 23 Oct 03).
} 
NIS approach. The NIS concept fits into a web of society, politics, and economics engineered (heterogeneously) by the actors responsible for its conception. Thus, the development of the innovation systems concept is not merely a technical achievement: As a response to the pressing global economic and geo-political situation of the time at which it emerged, embedded within it are societal, political, and economic considerations (in addition to technical). The socio-cultural and political situation surrounding the epistemic community or social group who developed the NIS concept shaped its norms and values, which in turn influenced the meaning it was given.

\subsection{The NIS Concept as a Refutation of the Linear Model of Innovation}

A recurrent theme in my interviews was the role that systems-thinking plays vis-à-vis what is commonly known as the 'linear' or 'pipeline' model of innovation, in which technology is viewed as applied science. ${ }^{43}$

Because the NIS concept was simultaneously situated in both the academic and policy worlds, the approach encapsulated one of the major challenges from the new and emerging field of innovation studies (see, for example, the 'Chain-Link Model,' Kline and Rosenberg 1986). As Smith observes, "the [national innovation] systems way was a way of, for the European Commission, to get away from linear-model type thinking" (Smith interview, 13 Oct 03).

Similarly, Metcalfe explains the reasons for the impact of NIS thought in policymaking when he says that, "I think [the NIS approach] took us away from that rather sterile debate about the linear model to recognize that

\footnotetext{
${ }^{43}$ See, for example, literature in the history of technology and in S\&TS, in particular: Mayr 1976: 671; Barnes 1982; Laudan 1984: 1-26; Layton 1987; Reich 1985; Kline 1995: 194-196; Swann 1996: 4-7; Pinch and Bijker 1987.
} 
because it was more systemic, it was more messy, and therefore there were lots of feedbacks and so the idea of it being just a straight linear progression now begins to look very questionable" (Metcalfe interview, 23 Oct 03). ${ }^{44}$

\section{Conclusions}

In this paper I have adopted a sociological and historical perspective, not only to show how apparent problems in the application of the NIS concept can be seen as strengths (by allowing widespread and flexible application), but also to adduce additional reasons for its success that have gone largely unnoticed. I have done this by organizing the paper topically around eight 'missing pieces': features of the NIS concept that are downplayed in the NIS literature or ambiguities/'debates' within the field.

From a perspective that in a broad sense brings the resources of S\&TS to bear on the issue as seen through a social constructivist lens, I have identified the key social groups and, to use the term I adopt, the 'epistemic community' into which they coalesced, and traced their motivations in developing the NIS concept as a social technology. I have shown how this epistemic community formed and how its formation resulted in the dissemination of the concept. In particular, fuzzy boundaries distinguishing

\footnotetext{
${ }^{44}$ In this respect, the Kline and Rosenberg (1986) paper was extremely influential in innovation studies in guiding the discussion among innovation systems scholars from the 1970s onwards; an influence my interviewees claimed must be underscored. Metcalfe, for example, states that "the paper by Nathan Rosenberg and Stephen J. Kline on the chain-link model ... . was a reaction to the linear model, [and] starts taking you into a systems perspective, starts getting more complicated, possibly getting more complex seeing that things are quite different" (Metcalfe interview, 23 Oct 03). Kline and Rosenberg disputed the 'linear' view of the innovation process that has underpinned the traditional approach to technology policy, arguing that scientific research frequently lags behind or relies on technological knowledge. Rather than comprising a sequence of phases or steps, the innovation process is more accurately portrayed as a set of activities (scientific, technological, design-oriented, and in engineering research and practice) that are linked to one another through complex feedback loops. Successful innovation relies on interaction among different activities. Moreover, they state, innovation is complex, uncertain, disorderly, and subject to changes of many sorts.
} 
academic and policy circles allowed for cross-fertilization by theoretical and practical considerations, and this accelerated the spread of the NIS concept. As I have argued, this makes the concept into a boundary object, further hastening its acceptance and use across this interdisciplinary community. Moreover, I have broadened the perspective still further, showing how the wider environment helped co-construct the NIS concept.

The epistemic community that comprised the NIS offshoot of the Schumpeterian movement-frustrated by the treatment of technical change in neoclassical economics—has now splintered into several subsidiary groups or smaller epistemic communities, depending on how various members have interpreted the NIS concept (focusing, for example, on technological and sectoral innovation systems). There is, then, more than one interpretation of the 'sociological fact' behind the social construction of the NIS concept. It is little wonder that in this environment closure has not been achieved in the debates in which the NIS-oriented groups are engaged. Individuals involved in the debates often seek to 'enroll' new individuals into their groups so as to form a new scheme, encouraging others to follow.

More generally, with these distinct but closely related social groups applying the NIS concept differently, stabilization and closure of the NIS approach remains to be achieved. One group seems to be pursuing a 'technical' solution to the problem of under-theorization (described in section 4.5) by further developing the theoretical basis of the concept, while another seems to be attempting to redefine the problem. The practical application of the (national) innovation systems concept is embedded in social choices and negotiations about what counts as an innovation system, what should count as the delimiting criterion (whether on a national or some other scale), and how to draw borders. These social choices and negotiations are made each 
time the innovation systems concept is used, or developed further, by any individual or group depending on their location on the 'map' of the larger field.

The social constructivist analysis presented here helps by drawing attention to the social factors and interpretations that the actors have adopted and that will determine the future utility of the NIS concept. In such a situation, the concept of a boundary object explains how the NIS builds bridges between the various social worlds of the stakeholders and at the same time maintains the coherence or integrity of the concept across distinct domains, in spite of the variations in meaning characterizing its use among the diverse groups. Even within the smaller or subsidiary groups (of the larger group), the NIS representation is flexible enough to permit all the various stakeholders, regardless of their positions, to arrive on the same page. This serves the analytic requirements of both the larger interdisciplinary epistemic community and the smaller sub-communities that focus on regional, sectoral, technological or other levels of analysis. 


\section{References}

Abbott, Andrew Delano. (1988). The system of professions: An essay on the division of expert labor. University of Chicago Press.

_. (2001). Chaos of disciplines. University of Chicago Press.

Adler, Emanuel \& Peter M. Haas. (1992). Conclusion: Epistemic communities, world order, and the creation of a reflective research program. International Organization 46 (1), 367-390.

Aghion, P. \& P. Howitt. (1992). A model of growth through creative destruction. Econometrica 60, 323-351.

Albert, Mathieu. (2001, November 2). The system of innovation approach. Paper presented at the meeting of the Society for the Social Studies of Science, Cambridge, MA.

Albert, Mathieu \& Suzanne Laberge. (2004, August 16). The legitimation and dissemination processes of the innovation system approach: The case of the Canadian and Quebec science and technology policy. Paper presented at the 99th American Sociological Association Annual Meeting, San Francisco.

Averch, Harvey A. (1985). A strategic analysis of science and technology policy. Baltimore: Johns Hopkins University Press.

Barnes, Barry. (1982). The science-technology relationship: A model and a query. Social Studies of Science 12 (1), 166-172.

Bell, D. (1973). The coming of post-industrial society: A venture in social forecasting. New York: Basic Books.

Bourdieu, Pierre. (1984). Distinction: A social critique of the judgment of taste. Cambridge, MA: Harvard University Press.

Bowker, Geoffrey C. \& Susan Leigh Star. (1999). Sorting things out: classification and its consequences. Cambridge, MA: MIT Press.

Branscomb, Lewis. (1987). National and corporate technology strategies in an interdependent world economy. In B. R. Guile, H. Brooks \& National Academy of Engineering (Eds.). Technology and global industry: Companies and nations in the world economy. Washington, DC: National Academy Press.

. (1993). Empowering technology: Implementing a U.S. strategy. Cambridge, MA: MIT Press. 
Breschi, Stefano \& Franco Malerba. (1997). Sectoral innovation systems: Technological regimes, Schumpeterian dynamics, and spatial boundaries. In C. Edquist (Ed.). Systems of Innovation: Technologies, institutions and organizations. London: Pinter.

Brooks, Harvey. (1993). Research universities and the social contract for science. In L. M. Branscomb (Ed.). Empowering technology: Implementing a U.S. strategy. Cambridge, MA: MIT Press.

Cambrosio, Alberto, Camille Limoges \& Denyse Pronovost. (1990). Representing biotechnology: An ethnography of Quebec science policy. Social Studies of Science 20 (2), 195-227.

Carlsson, Bo. (1994). Technological systems and economic performance. In M. Dodgson \& R. Rothwell (Eds.). The Handbook of Industrial Innovation. Cheltenham, UK: Edward Elgar.

(1995). Technological systems and economic performance: The case of factory automation. Dordrecht: Kluwer Academic Publishers.

(1996). Innovation and success in Sweden: Technological systems. In J. De la Mothe \& G. Paquet (Eds.). Evolutionary economics and the new international political economy. New York: Pinter.

Carlsson, Bo \& Staffan Jacobsson. (1997). Diversity creation and technological systems: A technology policy perspective. In C. Edquist (Ed.). Systems of innovation: Technologies, institutions and organizations. London: Pinter.

Castellacci, Fulvio, Stine Grodal, Sandro Mendonca \& Mona Wibe. (2005). Advances and challenges in innovation studies. Journal of Economic Issues 39 (1), 91-121.

Castells, Manuel. (2000). The rise of the network society ( $2^{\text {nd }}$ ed.). Oxford: Blackwell.

Chesnais, Francois. (1993). The French National System of Innovation. In National Innovation Systems: A Comparative Analysis, edited by R. R. Nelson. New York: Oxford University Press.

Cohen, Laurie, John McAuley \& Joanne Duberly. (2001). Continuity in discontinuity: Changing discourses of science in a market economy. Science, Technology \& Human Values 26 (2), 145-166.

Collins, H. M. \& T. J. Pinch. (1982). Frames of meaning: the social construction of extraordinary science. London: Routledge \& Kegan Paul.

Coombs, Rod. (2001). Technology and the market: Demand, users and innovation. Cheltenham, UK: Edward Elgar. 
Coombs, Rod, Paolo Saviotti \& Vivien Walsh. (1987). Economics and technological change. Totowa, NJ: Rowman \& Littlefield.

Cowan, Ruth Schwartz. (1987). The consumption junction: A proposal for research strategies in the sociology of technology. In W. E. Bijker, T. P. Hughes \& T. J. Pinch (Eds.). The social construction of technological systems: New directions in the sociology and history of technology. Cambridge, MA: MIT Press.

Dosi, Giovanni, Christopher Freeman, Richard R. Nelson, Gerald Silverberg \& Luc Soete. (1988). Technical change and economic theory. London: Pinter Publishers.

Drucker, Peter Ferdinand. (1969). The age of discontinuity: Guidelines to our changing society. New York: Harper \& Row.

Edquist, Charles. (1997). Systems of innovation: Technologies, institutions, and organizations. London: Pinter. (2005). Systems of innovation: Perspectives and challenges. In J. Fagerberg, D. Mowery \& R. Nelson (Eds.). Oxford Handbook of Innovation. Oxford University Press.

Edquist, Charles \& Bjorn Johnson. (1997). Institutions and organizations in systems of organization. In C. Edquist (Ed.). Systems of Innovation: Technologies, Institutions and Organizations. London: Pinter.

Edquist, Charles \& Maureen D. McKelvey. (2000). Systems of innovation: Growth, competitiveness, and employment. Cheltenham, UK: Edward Elgar.

Edquist, Charles \& Leif Hoemmen. (2004). Comparative framework for and proposed structure of the studies of national innovation systems in ten small countries. Lund: Division of Innovation, Lund Institute of Technology, Lund University, Sweden.

Etzkowitz, Henry \& Loet A. Leydesdorff. (1997). Universities and the global knowledge economy: A triple helix of university-industry-government relations. London: Pinter.

(1998). The Endless Transition: A "triple helix" of university-industrygovernment. Minerva 36, 203-208.

- (2000). The dynamics of innovation: From national systems and "mode 2 " to a triple helix of university-industry-government relations. Research Policy 29, 109-123.

Fagerberg, Jan, David Mowery \& Richard Nelson (Eds.). (2005). Oxford handbook of innovations. Oxford University Press. 
Foray, Dominique \& Christopher Freeman (Eds.) (1993). Technology and the wealth of nations: The dynamics of constructed advantage. New York: St. Martin's Press.

Freeman, Christopher. (1982). Technological infrastructure and international competitiveness. Paper presented to the ad hoc group on Science, Technology and Competitiveness. Paris: Organisation for Economic Co-operation and Development.

- (1987). Technology, policy, and economic performance: Lessons from Japan. London: Pinter Publishers.

(1988). Japan: a new national system of innovation? In Technical Change and Economic Theory, edited by G. Dosi. London: Pinter Publishers

- (1995). The national innovation system in historical perspective. Cambridge Journal of Economics 19 (1), 41-60.

- (2004). Technological infrastructure and international competitiveness. Industrial and Corporate Change 13 (3), 541-569.

Freeman, Christopher \& Bengt-Åke Lundvall. (1988). Small countries facing the technological revolution. London: Pinter.

Gibbons, Michael. (1994). The new production of knowledge: The dynamics of science and research in contemporary societies. London: Sage Publications.

Gilpin, Robert. (1968). France in the age of the scientific state. Princeton University Press.

Godin, Benoît \& Yves Gingras. (2000). The place of universities in the system of knowledge production. Research Policy 29, 273-278.

Grossman, G.M. \& E. Helpman. (1991). Innovation and growth in the global economy. Cambridge, MA: MIT Press.

Guinet, Jean. (1996). Recent OECD Work on National Innovation Systems. In Institutional and entrepreneurial leadership in the Brazilian science and technology sector: Setting a new agenda, edited by L. Holm Nielsen, M. Crawford and A. Saliba. Washington, D.C: World Bank.

Guinet, Jean \& Organisation for Economic Co-operation and Development. (1995). National systems for financing innovation. Paris: Organisation for Economic Co-operation and Development.

Guston, David H. (2000). Between politics and science: Assuring the integrity and productivity of research. Cambridge University Press. 
Haas, Ernst B. (1990). When knowledge is power: Three models of change in international organizations. Berkeley, CA: University of California Press.

Haas, Peter M. (1992). Introduction: Epistemic communities and international policy coordination. International Organization 46 (1), 1-35.

Hicks, Diana \& J. Sylvan Katz. (1996). Where is science going? Science, Technology \& Human Values 21, 379-406.

Hippel, Eric von. (1976). The dominant role of users in the scientific Instrument innovation process. Research Policy 5, 212-239.

- (1988). The sources of innovation. Oxford University Press.

Jääskelainen, Jari. (2001). Cluster - between science and policy. From industrial policy to social policy. Helsinki: ETLA.

Jacobsson, Staffan. (1997). Sweden's Technological System for Electronics and Computer Technology. In Technological systems and industrial dynamics, edited by B. Carlsson. Boston: Kluwer Academic Publishers. . (1997). Systems Transformation: Technological and Institutional Change. In Systems of Innovation: Technologies, Institutions and Organizations, edited by C. Edquist. London: Pinter.

Jansen, Jonathan D. (2002). Mode 2 knowledge and institutional life: Taking Gibbons on a walk through a South African University. Higher Education 43 (4), 507-521.

Jasanoff, Sheila. (1996). Science and Norms in Global Environmental Regimes. In F. O. Hampson. \& J. Reppy (Eds.). Earthly goods: Environmental change and social justice. Ithaca, NY: Cornell University Press.

Johnson, Chalmers A. (1982). MITI and the Japanese miracle: the growth of industrial policy, 1925-1975. Stanford: Stanford University Press.

Kline, Ronald R. (1992). Construing "technology" as "applied science": Public rhetoric of scientists and engineers in the United States, 1880-1945. ISIS 86, 194-221.

Kline, Stephen J. \& Nathan Rosenberg. (1986). An overview of innovation. In R. Landau \& N. Rosenberg (Eds.). The positive sum strategy: Harnessing technology for economic growth. Washington, DC: National Academy Press.

Knorr-Cetina, K. (1999). Epistemic cultures: How the sciences make knowledge. Cambridge, MA: Harvard University Press. 
Kuhn, Thomas S. (1962). The structure of scientific revolutions. Chicago: University of Chicago Press

Latour, Bruno. (1987). Science in action: How to follow scientists and engineers through society. Cambridge, MA: Harvard University Press.

- (1996). Aramis, or, the love of technology. Cambridge, MA: Harvard University Press.

Laudan, Rachel. (1984). The nature of technological knowledge: Are models of scientific change relevant? Dordrecht: Reidel.

Layton, Edwin. (1987). Through the looking glass, or news from lake mirror image. Technology and Culture 28 (3), 594-607.

Leijonhufvud, Axel. (1981). Life among the econ. In A. Leijonhufvud (Ed.). Information and coordination: Essays in macroeconomic theory. Oxford University Press.

List, Friedrich. (1841). Das nationale der politischen oekonomie. Stuttgart: Cotta.

Lundvall, Bengt-Åke. (1985). Product innovation and user-producer interaction. Denmark: Aalborg University Press.

Lundvall, Bengt-Åke. (1988). Innovation as an interactive process: from userproducer interaction to the national system of innovation. In Technical Change and Economic Theory, edited by G. Dosi. London: Pinter Publishers.

(1992). National systems of innovation: Towards a theory of innovation and interactive learning. London: Pinter.

. (1993). User-producer relationships, national systems of innovation, and internationalization. In D. Foray \& C. Freeman (Eds.). Technology and the wealth of nations: The dynamics of constructed advantage. London: Pinter.

. (1998). Why study national systems and national styles of innovation? Technology Analysis \& Strategic Management 10 (4), 407-421.

(2003, September 4-5). National innovation systems: History and theory. Paper presented at the NSTDA-JICA Seminar on Innovation Systems in Asian Economies. Bangkok, Thailand.

. (2004). Introduction to 'technological infrastructure and international competitiveness' by Christopher Freeman. Industrial and Corporate Change 13 (3), 531-539. 
Lundvall, Bengt-Åke, Bjorn Johnson, Esben Sloth Andersen \& Bent Dalum. (2001, June 12-15). National systems of production, innovation and competence-building. Paper presented at the Nelson and Winter DRUID Summer Conference. Aalborg Congress Center, Aalborg, Denmark.

- (2002). National Systems of Production, Innovation and Competencebuilding. Research Policy 31 (2), 213-231.

Lundvall, Bengt-Åke, Patarapong Intarakumnerd \& Jan Vang. (Eds.). (2006). [Forthcoming]. Asian Innovation Systems in Transition. Cheltenham, UK: Edward Elgar.

Lynch, Michael. (1998). Towards a constructivist genealogy of social constructivism. In I. Velody and R. Williams (Eds.). The politics of constructionism. London: Sage Publications.

Malerba, Franco. (2004). Sectoral systems of innovation. Cambridge University Press. . (2005). Sectoral systems: How and why innovation differs across sectors. In J. Fagerberg, D. Mowery \& R. Nelson (Eds.). Oxford Handbook of Innovation. Oxford University Press.

Masterman, Margaret. (1970). The nature of a paradigm. In I. Lakatos \& A. Musgrave (Eds.). Criticism and the growth of knowledge: Proceedings of the International Colloquium in the Philosophy of Science, London, (1965), Vol. 4. Cambridge University Press.

Matthews, Michael R. (1998). Constructivism in science education: A philosophical examination. Dordrecht: Kluwer Academic.

Mayr, Otto. (1976). The science-technology relationship as an historiographic problem. Technology and Culture 17, 663-672.

McKelvey, Maureen D. (1996). Evolutionary innovations : the business of biotechnology. Oxford: Oxford University Press.

Metcalfe, S. (1995). The economic foundations of technology policy: Equilibrium and evolutionary perspectives. In P. Stoneman (Ed.). Handbook of the economics of innovations and technological change. Oxford, U.K: Blackwell. . (1997). Technology systems and technology policy in an evolutionary framework. In Technology, globalisation and economic performance, edited by D. Archibugi and J. Michie. Cambridge: Cambridge University Press.

Metcalfe, S. \& I Miles. (2000). Innovation Systems in the Service Economy. London: Kluwer Academic Publishers 
Miettinen, Reijo. (2002). National innovation system: Scientific concept or political rhetoric. Helsinki: Edita Prima Ltd.

Muchie, Mammo, Peter Gammeltoft \& Bengt-Åke Lundvall. (2003). Putting Africa first: The making of African innovation systems. Denmark: Aalborg University Press.

Nelson, Richard R. (1988). Institutions supporting technical change in the United States. In Technical Change and Economic Theory, edited by G. Dosi. London: Pinter Publishers.

(Ed.). (1993). National innovation systems: A comparative analysis. Oxford University Press.

(2000). National innovation systems. In Z. J. Acs (Ed.). Regional innovation, knowledge and global change, London: Pinter.

. (2004, June 9-12). Where are we now on an evolutionary theory of economic growth, and where should we be going? Paper presented at the 10th Conference of the International J. A. Schumpeter Society: Innovation, industrial dynamics, and structural transformation: Structural legacies. Milan, Italy.

Nelson, Richard \& Charles Rosenberg. (1993). Technical innovation and national systems. In R. R. Nelson (Ed.). National innovation systems: A comparative analysis. Oxford University Press.

Organisation for Economic Co-operation and Development. (1992). Technology and the economy: The key relationships. Paris: Organisation for Economic Co-operation and Development. (1999). Managing national innovation systems. Paris: Organisation for Economic Co-operation and Development.

Oudshoorn, Nelly \& T. J. Pinch. (2003). How users matter: The coconstruction of users and technologies. Cambridge, MA: MIT Press.

Pestre, Dominique. (2003). Regimes of knowledge production in society: Toward a more political and social reading. Minerva 41, 245-261.

Pinch, Trevor J. and Wiebe E. Bijker. (1987). The Social Construction of Facts and Artifacts: Or How the Sociology of Science and the Sociology of Technology Might Benefit Each Other. In The Social Construction of Technological Systems : New Directions in the Sociology and History of Technology, edited by W. E. Bijker, T. P. Hughes and T. J. Pinch. Cambridge, Massachusetts: The MIT Press.

Porter, Michael E. (1990). The competitive advantage of nations. New York: Free Press. 
Reich, Leonard S. (1985). The making of American industrial research: Science and business at GE and Bell, 1876-1926. Cambridge University Press.

Reinert, Erik. (1999). The role of the state in economic growth. Journal of Economic Studies 26 (4/5), 268-326.

- (2003). The other canon: The history of renaissance economics. In E. Reinert (Ed.). Evolutionary Economics and Income Inequality. Cheltenham, UK: Edward Elgar.

Romer, P.M. (1986). Increasing returns and long-run growth. Journal of Political Economy 98, 71-102.

_. (1990). Endogenous technological change. Journal of Political Economy 98, S71-S102.

Samuels, Richard J. (1994). "Rich nation, strong Army": National security and the technological transformation of Japan. Ithaca, NY: Cornell University Press.

Schumpeter, Joseph Alois \& Redvers Opie. (1934). The theory of economic development: An inquiry into profits, capital, credit, interest, and the business cycle. Cambridge, MA: Harvard University Press.

Schumpeter, Joseph Alois. (1962). Capitalism, socialism, and democracy. New York: Harper.

Sharif, Naubahar. (2003). The role of firms in the national innovation system framework: Examples from Hong Kong. Innovation: Management, Policy and Practice 5 (2-3), 189-199.

- (2004). Contributions from the sociology of technology to the study of innovation systems. Knowledge, Technology \& Policy 17 (3-4), 83-105.

Shils, Edward. (1968). Criteria for scientific development: Public policy and national goals: A selection of articles from Minerva. Cambridge, MA: MIT Press.

Shinn, Terry. (2002). The triple helix and new production of knowledge. Social Studies of Science 32 (4), 599-614.

Sismondo, Sergio. (2004). An introduction to science and technology studies. Malden, MA: Blackwell.

Slezak, Peter. (1989). Scientific discovery by computer as empirical refutation of the strong programme. Social Studies of Science 19, 563-600. 
(1994). Sociology of science and science education. Science \& Education 3 (3), 265-294.

Smith, Keith. (1997). Economic Infrastructures and Innovation Systems. In Systems of Innovation: Technologies, Institutions and Organizations, edited by $\mathrm{C}$. Edquist. London: Pinter.

Solow, Robert M. (1957). Technical change and the aggregate production function. Review of Economics and Statistics 39 (3), 312-320.

Star, Susan Leigh \& James R. Griesemer. (1989). Institutional ecology, 'translations,' and boundary objects: Amateurs and professionals in Berkeley's Museum of Vertebrate Zoology, 1907-39. Social Studies of Science 19 (4), 387-420.

Swann, Peter. (1996). The economic value of publicly funded research: A framework for assessing the evidence. In A Report Written for Branch 4, Technology and Innovation Division (DTI), UK. Manchester: PREST, University of Manchester.

Vogel, Ezra F. (1979). Japan as number one: Lessons for America. Cambridge, MA: Harvard University Press.

Vuori, Synnöve \& Pentti Vuorinen. (1994). Explaining technical change in a small country: the Finnish national innovation system. Helsinki, Finland: Physica-Verlag in association with ETLA.

Wajcman, Judy. (1991). Feminism confronts technology. University Park, PA: Pennsylvania State University Press.

Weintraub, E. Roy. (2002). How economics became a mathematical science. Durham, NC: Duke University Press.

Whitley, Richard. (1983). The structure and context of economics as a scientific field. In R. Samuels (Ed.). Research in the history of economic thought and methodology. Greenwich, CT: JAI Press.

- (1984). The intellectual and social organization of the sciences. Oxford: Clarendon Press.

Woolgar, Steve. (1991). Configuring the user: The case of usability trials. In J. Law (Ed.). A sociology of monsters: Essays on power, technology, and domination. London: Routledge.

Ziman, J. M. (2000). Real science: What it is, and what it means. Cambridge University Press. 
Table 1: $\quad$ Formal Interviews: Emergence of the NIS Concept

\begin{tabular}{|c|c|c|c|}
\hline $\begin{array}{l}\text { Name of Person } \\
\text { Interviewed }\end{array}$ & $\begin{array}{c}\text { Institutional } \\
\text { Affiliation at Time } \\
\text { of Interview }\end{array}$ & $\begin{array}{c}\text { Major role in } \\
\text { development of NIS } \\
\text { concept (publication, } \\
\text { policy role, or other role) }\end{array}$ & $\begin{array}{c}\text { Date and location } \\
\text { of interview }\end{array}$ \\
\hline $\begin{array}{l}\text { 1. Christopher } \\
\text { Freeman }\end{array}$ & $\begin{array}{l}\text { University of } \\
\text { Sussex, England }\end{array}$ & Freeman, 1987 & $\begin{array}{l}24 \text { Oct } 03, \\
\text { Brighton, England }\end{array}$ \\
\hline $\begin{array}{l}\text { 2. Richard } \\
\text { Nelson }\end{array}$ & $\begin{array}{l}\text { Columbia } \\
\text { University, USA }\end{array}$ & Nelson, 1993 & $\begin{array}{l}10 \text { Nov 03, New } \\
\text { York, USA }\end{array}$ \\
\hline $\begin{array}{l}\text { 3. Bengt-Åke } \\
\text { Lundvall }\end{array}$ & $\begin{array}{l}\text { Aalborg University, } \\
\text { Denmark }\end{array}$ & Lundvall, 1992 & $\begin{array}{l}20 \text { Oct 03, Aalborg, } \\
\text { Denmark }\end{array}$ \\
\hline $\begin{array}{l}\text { 4. Charles } \\
\text { Edquist }\end{array}$ & $\begin{array}{l}\text { Lund University, } \\
\text { Sweden }\end{array}$ & $\begin{array}{l}\text { Edquist, 1997; Edquist } \\
\text { and McKelvey, 2000; } \\
\text { Edquist 2005 }\end{array}$ & $\begin{array}{l}21 \text { Oct 03, Lund, } \\
\text { Sweden }\end{array}$ \\
\hline $\begin{array}{l}\text { 5. Maureen } \\
\text { McKelvey }\end{array}$ & $\begin{array}{l}\text { Chalmers Univ. of } \\
\text { Tech., Sweden }\end{array}$ & $\begin{array}{l}\text { McKelvey, } 2000 \text { (edited } \\
\text { with Edquist) }\end{array}$ & $\begin{array}{l}18 \text { Oct } 03, \\
\text { Alingsås, Sweden }\end{array}$ \\
\hline 6. Keith Smith & $\begin{array}{l}\text { Chalmers Univ. of } \\
\text { Tech., Sweden }\end{array}$ & $\begin{array}{l}\text { Smith 1997; Finnish } \\
\text { Technology Policy; } \\
\text { OECD }\end{array}$ & $\begin{array}{l}13 \text { Oct } 03, \\
\text { Gothenburg, } \\
\text { Sweden }\end{array}$ \\
\hline $\begin{array}{l}\text { 7. Staffan } \\
\text { Jacobsson }\end{array}$ & $\begin{array}{l}\text { Chalmers Univ. of } \\
\text { Tech., Sweden }\end{array}$ & Jacobsson 1997a, 1997b & $\begin{array}{l}17 \text { Oct } 03, \\
\text { Gothenburg, } \\
\text { Sweden }\end{array}$ \\
\hline 8. Rod Coombs & $\begin{array}{l}\text { University of } \\
\text { Manchester }\end{array}$ & $\begin{array}{l}\text { Coombs et al. 1987; } \\
\text { Coombs 2001; PREST } \\
\text { Group, Univ. of } \\
\text { Manchester }\end{array}$ & $\begin{array}{l}23 \text { Oct } 03, \\
\text { Manchester, } \\
\text { England }\end{array}$ \\
\hline $\begin{array}{l}\text { 9. Stanley } \\
\text { Metcalfe }\end{array}$ & $\begin{array}{l}\text { University of } \\
\text { Manchester }\end{array}$ & $\begin{array}{l}\text { Metcalfe, 1995; Metcalfe, } \\
\text { 1997; Metcalfe and Miles, } \\
2000 .\end{array}$ & $\begin{array}{l}23 \text { Oct 03, } \\
\text { Manchester, } \\
\text { England }\end{array}$ \\
\hline $\begin{array}{l}\text { 10. Franco } \\
\text { Malerba }\end{array}$ & $\begin{array}{l}\text { Università Bocconi, } \\
\text { Milan, Italy }\end{array}$ & Malerba, 2004 & $\begin{array}{l}27 \text { Oct } 03, \text { Milan, } \\
\text { Italy }\end{array}$ \\
\hline $\begin{array}{l}\text { 11. Francois } \\
\text { Chesnais }\end{array}$ & Retired & $\begin{array}{l}\text { Chesnais 1993; } \\
\text { Responsible for the } \\
\text { publication of the OECD } \\
1992 \text { volume and former } \\
\text { OECD principal } \\
\text { administrator of the } \\
\text { Directorate for Science, } \\
\text { Technology and Industry } \\
\text { (DSTI) }\end{array}$ & $\begin{array}{l}29 \text { Oct 03, Paris, } \\
\text { France }\end{array}$ \\
\hline 12. Jean Guinet & $\begin{array}{l}\text { OECD, Paris, } \\
\text { France }\end{array}$ & $\begin{array}{l}\text { Guinet, 1995, 1996; } \\
\text { Current OECD and } \\
\text { principal administrator of } \\
\text { the Directorate for } \\
\text { Science, Technology and } \\
\text { Industry (DSTI) }\end{array}$ & $\begin{array}{l}28 \text { Oct } 03, \text { Paris, } \\
\text { France }\end{array}$ \\
\hline
\end{tabular}

${ }^{\text {a }}$ See reference list for citations to these authors, where applicable. 
Table 2: Informal Conversations: Emergence of the NIS Concept

\begin{tabular}{|l|l|l|l|}
\hline $\begin{array}{c}\text { Name of Person } \\
\text { Interviewed }\end{array}$ & $\begin{array}{c}\text { Institutional } \\
\text { Affiliation at Time } \\
\text { of Conversation }\end{array}$ & $\begin{array}{l}\text { Major role in development } \\
\text { of NIS concept } \\
\text { (publication, policy role, or } \\
\text { other role) }\end{array}$ & $\begin{array}{c}\text { a } \\
\text { Location of } \\
\text { Conversation }\end{array}$ \\
\hline $\begin{array}{l}\text { 1. Pekka Ylä- } \\
\text { Antilla }\end{array}$ & $\begin{array}{l}\text { ETLA, Helsinki, } \\
\text { Finland }\end{array}$ & $\begin{array}{l}\text { S\&T Policy Council of } \\
\text { Finland }\end{array}$ & $\begin{array}{l}\text { 26 Nov 03, } \\
\text { Taipei, Taiwan }\end{array}$ \\
\hline 2. Birgitte & $\begin{array}{l}\text { Aalborg University, } \\
\text { Genmark }\end{array}$ & $\begin{array}{l}\text { Gregersen, 1988; IKE } \\
\text { Group, Aalborg, Denmark }\end{array}$ & $\begin{array}{l}\text { 27 Nov 03, } \\
\text { Taipei, Taiwan }\end{array}$ \\
\hline 3. David Mowery & $\begin{array}{l}\text { University of } \\
\text { California, Berkeley }\end{array}$ & $\begin{array}{l}\text { Fagerberg, Mowery and } \\
\text { Nelson 2005 }\end{array}$ & $\begin{array}{l}\text { 31 May 04, } \\
\text { Lisbon, Portugal }\end{array}$ \\
\hline 4. Erik Reinert & $\begin{array}{l}\text { The Other Canon } \\
\text { Foundation, Norway }\end{array}$ & $\begin{array}{l}\text { History of knowledge-based } \\
\text { economic theory (Reinert } \\
\text { 1999, 2003) }\end{array}$ & $\begin{array}{l}\text { 11 Jun 04, Milan, } \\
\text { Italy }\end{array}$ \\
\hline 5. Bo Carlsson & $\begin{array}{l}\text { Case Western } \\
\text { Reserve University, } \\
\text { USA }\end{array}$ & $\begin{array}{l}\text { Technological innovation } \\
\text { systems (Carlsson } \\
\text { 1994,1995, 1996) }\end{array}$ & $\begin{array}{l}\text { 15 Jun 04, } \\
\text { Copenhagen, } \\
\text { Denmark }\end{array}$ \\
\hline
\end{tabular}

a See reference list for citations to these authors, where applicable. 


\section{Appendix: Key Figures in the History of the NIS Concept}

I present here the key figures in the emergence of the NIS concept, in the context of their institutional affiliations and professional and intellectual relationships. It is instructive to note the broad geographical and disciplinary sweep of the epistemic community in question as revealed by a review of the university departments that most of them call home.

The most notable of these departments is the Science Policy Research Unit (SPRU) at the University of Sussex, England. SPRU houses one of the most respected living founders of innovation research-Professor Emeritus, Christopher Freeman. SPRU was also the intellectual home of the late Keith Pavitt. Also in England at the University of Manchester are Stanley Metcalfe (who has extensively researched issues related to technology policy and innovation systems in the service economy) and Rod Coombs (who has worked on issues of private sector R\&D, focusing on company-level strategy).

The largest concentration of innovation studies scholars can be found, however, in Scandinavia. Bengt-Åke Lundvall, at the University of Aalborg in Denmark (where he credits Esben Sloth Andersen for much of the early pioneering work carried out in Aalborg), continues to be a key actor in promoting the innovation systems concept. In Sweden, Charles Edquist and Maureen McKelvey jointly worked on the concept of innovation systems at Linköping University in the early 1990s, before both of them left Linköping, with Edquist moving to Lund University, and McKelvey moving to Chalmers University of Technology in 2000 (in Lund and Gothenburg, Sweden, respectively). At Chalmers, McKelvey joined Staffan Jacobsson's Department of Industrial Dynamics which he set up in $1990 .{ }^{45}$ Jacobsson is

\footnotetext{
${ }^{45}$ Jacobsson was professor and Head of the Department of Industrial Dynamics and he was responsible for recruiting McKelvey. Prior to McKelvey's arrival, Jacobsson and his colleagues analyzed the dynamics of innovation systems in the fields of energy, biotechnology and telecommunications and they also did work on policy and on technology indicators.
} 
interested primarily in the concept of technological innovation systems. Keith Smith occupied a variety of positions in Scandinavia, including a post in Norway, and also served as advisor to the OECD while the innovation systems concept was being introduced. Norway is also the intellectual home of Jan Fagerberg, at the University of Oslo's Center for Technology, Innovation and Culture (TIK).

No less prominent are the research units in continental Europe which are the intellectual homes of scholars working explicitly within the innovation systems area. Among the most influential of this group is Luc Soete of Maastricht Economic Research Institute on Innovation and Technology (MERIT) and The United Nations University, The Netherlands, and Bart Verspagen at the Eindhoven Center for Innovation Studies. Others include Franco Malerba at Universitá Bocconi in Milan, Italy (Malerba works on sectoral innovation systems) and in the OECD the current Senior Administrator at the DSTI, Jean Guinet, and the former Senior Administrator at the DSTI, Francois Chesnais.

In the United States, a smaller concentration of academics and policymakers-closely tied to the European community of scholars and policymakers—has adopted such an interdisciplinary perspective, but Richard Nelson from Columbia University, Sidney Winter (University of Pennsylvania), David Mowery from the University of California, Berkeley, and Nathan Rosenberg (Professor Emeritus at Stanford University) have made notable and substantial contributions (past and present) to the development of the innovation systems concept. At Case Western Reserve University in Ohio, Bo Carlsson is active in the study of technological innovation systems.

While the above list is by not exhaustive, it identifies the universally acknowledged 'usual suspects' involved with innovation systems research. I interviewed most of the above individuals during the autumn of 2003. 